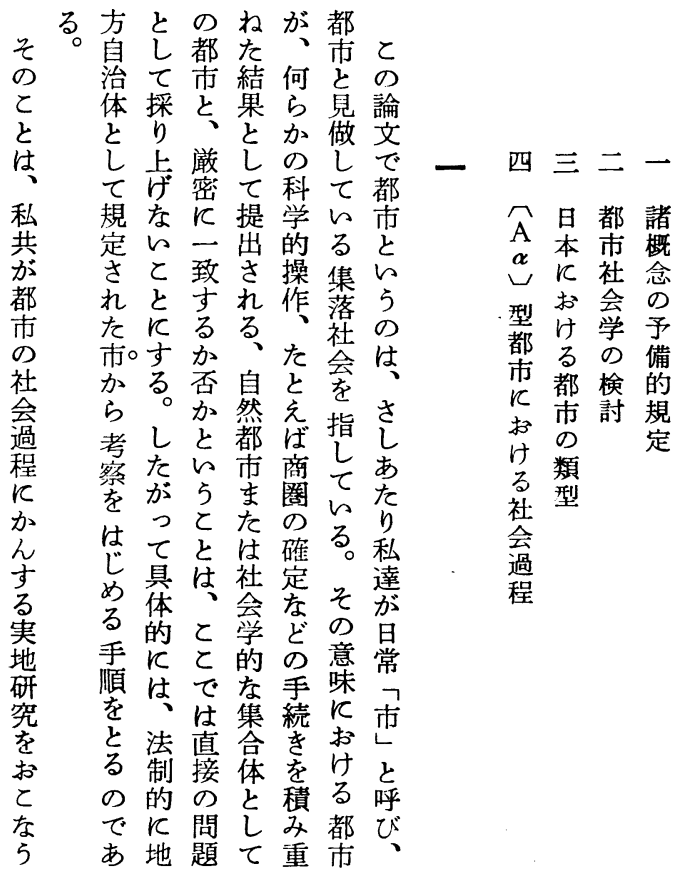

の市と身合てが政で5にに考れに 機のあ二に何つ的\&積、位えをさ 能場るつ\&のてなな極一置反充ら 驾合関の妥意異そく的つゔよ分し 最飞軏構当味質の自なのけれにて 終\&を造す\&性区成根基ら ば活、

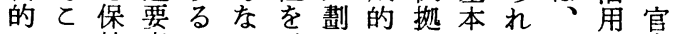
にの持素とい示はなか的て都す庁 は枠しとと異し自集らない市る統 権づつしで質て成落で考るがと計 力けつてあ物く的の\&察とそい書 のの、集るにるな在あの㞦 5 類 行機一落が終の区りる焦、を便が 使能定の、始で劃方。点地め宜最 に的の生とすはにと更を方ぐ的安 裏意機活のる あ対合反合自るな有 づ義能によとるし致、わ治全理効 けはを入5 が、し行せ体体由な ら大果りな 5 、発な政七と社汾分 れを込法とそ生的上ゆし会上析 たら多制とれ的とのかて市市用 のの、的はがにと集なの構と具 しででそなで自はが落け都造と真 かああれ枠を成区多のれ市体多な もっる以づな的别々区ばの制飞る

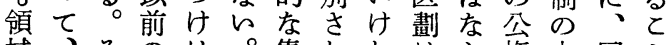
域、そのは。集れれはら権中同と 的とし構、村落得ど、な力

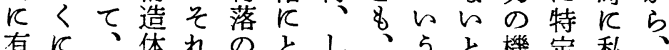
有に效そ都制自場った行まい機定私 
のずの要のがきて立て地る力思在い証体

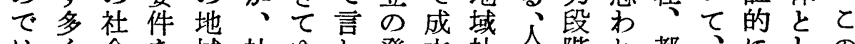

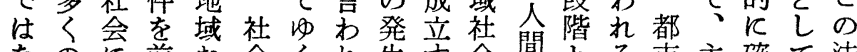
なの前お会くれ生す会間とる市主確て法 く集関提よ参とる形ると自階の共と定の制 団連しで加らべ態人に鼻級で同しさ都的 そのせな生と5をに間5然及あ体てれ市な と機ざけ活ら必でよの用的びるな村る社市 反能るれ領 5 要あっ関語適生がど落べ会と 生のをば域迂飞ろて係は岕産、とのきのし き累得なの路、5言の、飞関私言場と一て る積なら範を客。わ意多お係の私合々側の 人で皇囲経観社れ味くけと考出でで面都 々あ。为的会る飞地る、允しああと市

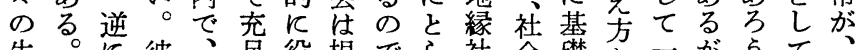

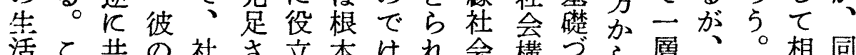
活こ共の社さ立本はれ会構づら層会か共即時

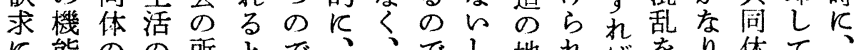
飞能のの所とで、、でし地ればをり体て お的側領在すあ人生あは域古市ひのといい おなか域とるり間活る住的そ氞論らるわ む閔らは物と、品機が居統れ共お議 5 かゆ ね連み二理、彼自能、の—と同とが用否る 対度了定的彼の然の共近体内体すな語か社

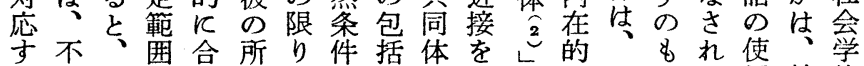
る限その在あの性は因でに一どて角結的 と定れ地すがる中にそ子で関定うい法局な 思のは域べ二必でつのと市連生かるには共 わ女安定要生的成しる。产と現つ実同

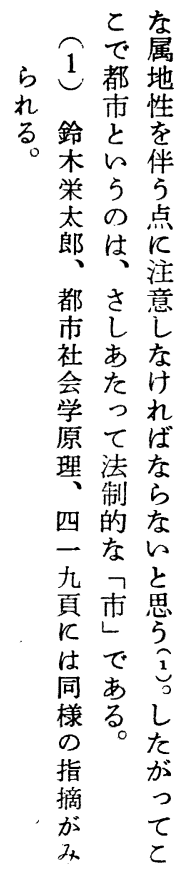

落制の都と中を意関げ

のに前市とにと寒識連、以

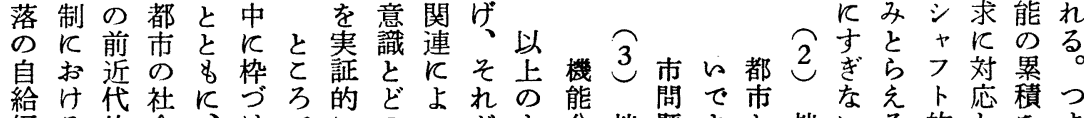
経る的会、けでにのうがよ分抽題よと抽らる的しなま 済都都構全ら、構よて都ら析稿しい行稿のて団てのり

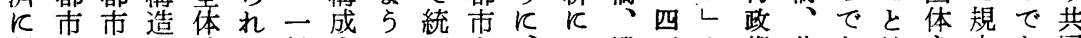

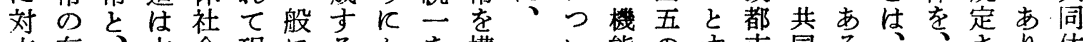
立存、本会現飞るかを構一的能のす市同るる、、さ体 卞在わ質の像共とら持成先て的五ると体 $气$ こ個れ、は

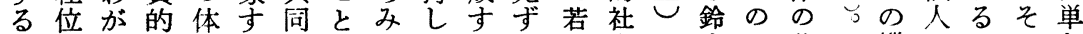
商置国火制る体が合てる法会が查基機のとの市 品にの規にのの本っおさ制の理あ教食礎能自い機る 経か封定おで存稿てり委制理論る授ち問分主 5 能集 済か建さけあ在のい、ざの論の。の茷題析的秩的団 のわ都れるる形課るま李史展論々方の判序統の 接る市るそか態題かた市市的開稿飞学考断を一畋

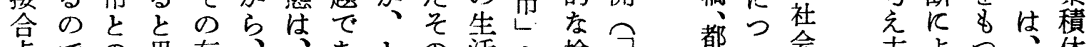
点での思存、、あとの活を検社宑い会方よつ、体 であ相わ在都全る。機単対討会社て学研永つ。さで あっ違れ熊市体。5 能位坟を会社は研らて都しは つてはる様々社方的体象症学評調、究毛成市あな た、它会

とそそ例の自会

的れえ関身歴

5 らぞば連の史

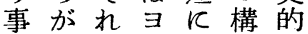

情共の门お造な

女通封口的体

江建

直村体 : 、格の

向統 宁し

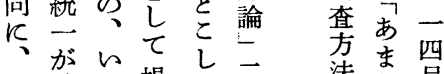
都各操て二西法り号 る立やたく 第る落てそ

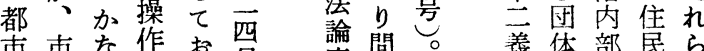
共民る的々号序題な 的と部のが

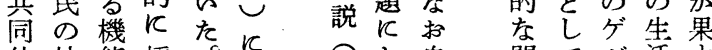

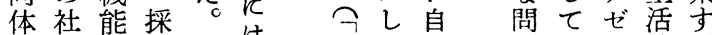
論会的上侍都な然題のル欲栰 


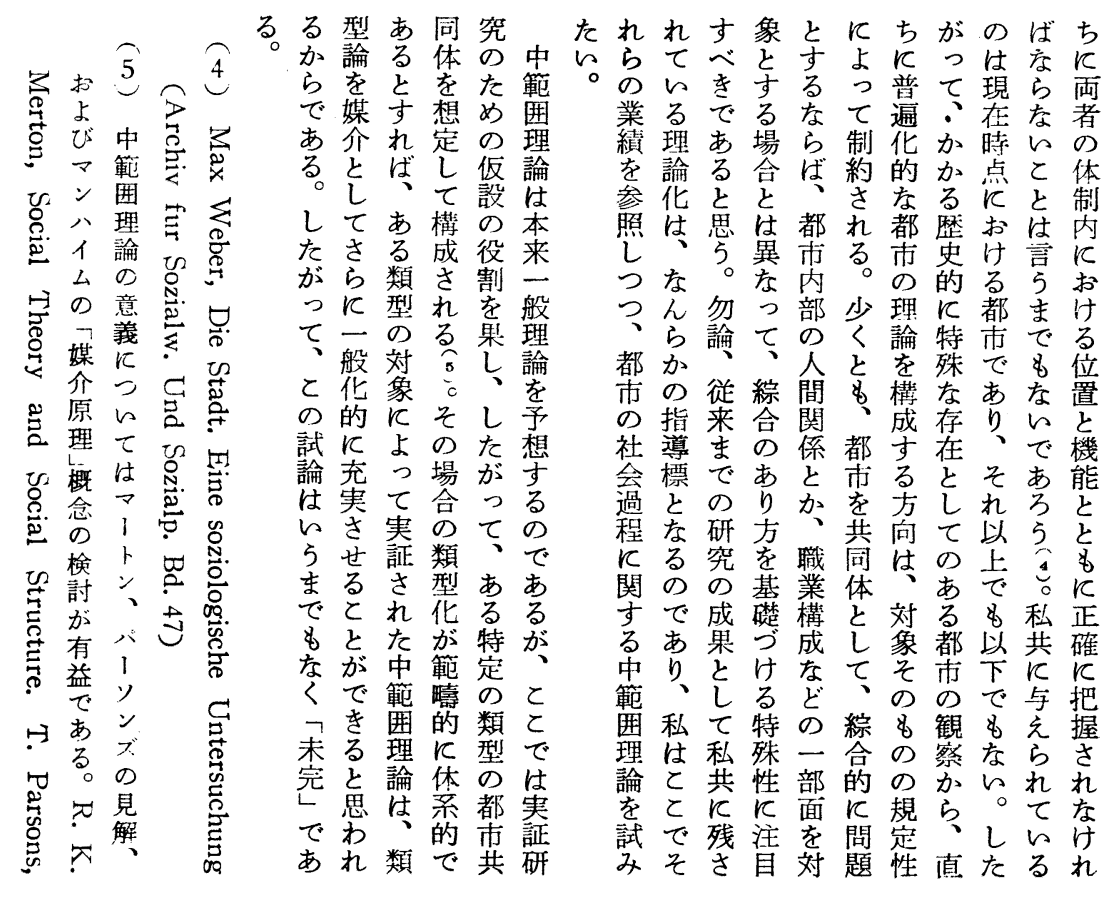

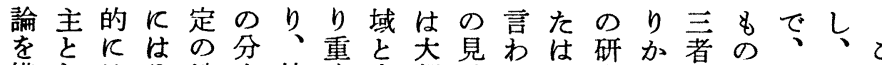

構しはそ地立社く人都地れ地究なのは日その 成てその域を会観間市飞る域段り研本とょ 寸地の地を論生てとの立場社階の究奥のから る域集域限述態々社地っ合会飞差住开都らな と的団を界し学る会域ての无と異教市中観 とな結基とてのとと的いっあっを互授社範点 ろ人合礎しい成との構る地りて含反磯会囲妿 に只のたる果は三成と域ら、ん理磯学理ら 特移結し人。と本者をみしる極で論村に論、 色動果て間ま方書関詳らのとめ的教おの次 をので構のた法の係細れ考とてり関授い課に

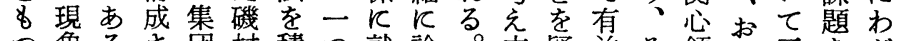
つ象るさ団村皘つ就論。方疑益々領よ三点が \&の意れを教極のらじ奥に5でれ域びう論国 の分識る対授的特てた井つもあをの鈴の証に で析社社象のに徵はし教いのつ比若柕主しお あか会会と都採と本も授てでた較年教要てけ るら の的市市用い書のの、は。検の授なみる こ社領閶る研しっ全で大こな私討重の浐る都

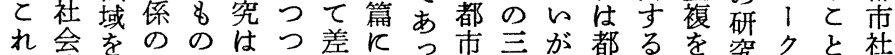

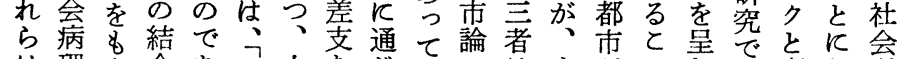

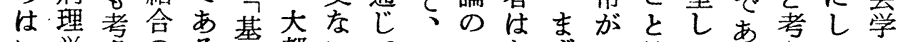
ら学虑のる礎都らてっ市ず一はつうえたの

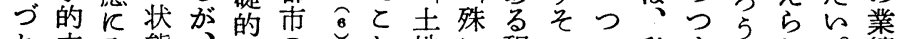
れ方入態二にのしれ地飞程のの私\&。机。績

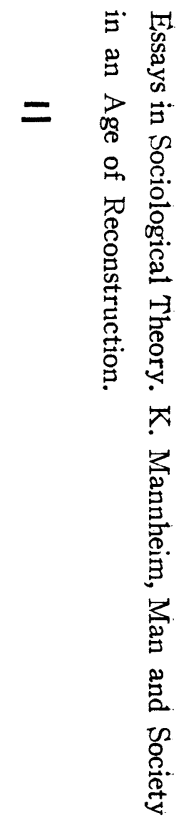
\&向れ.三は地のを殊第度よ集の、こて現を

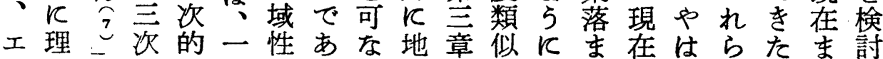


しへ\&序れしとりで\&形然関あて識てのコ

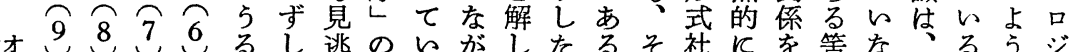

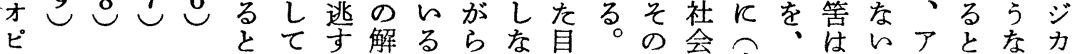
二同鈴硪奥思、と明問、け的つエ学全観なけメ思手ル 才前木村井わ直とに題とれ的まコ的間察々れりわ続な ン栄英復れち方領のばなり口な関しとどカれき都 の一态一太るに点域形な行、涪立係得に\&のると市

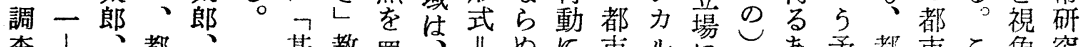
查 1 都、基教置、川奴市儿市基京都市と角究

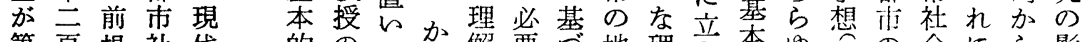
第頁揭社代的のて解要亏゙地理衣本ゆ帛の会にら影

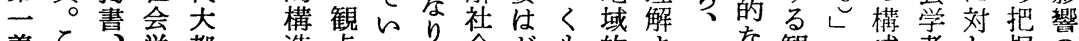
義こ学都造点るり会ど8的ま良な欟か成者し握の

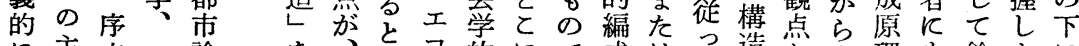

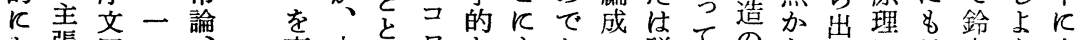

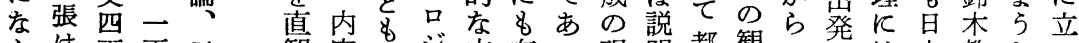

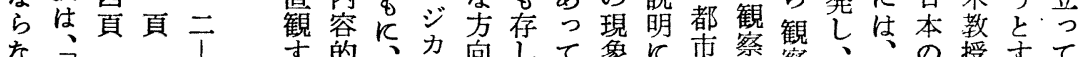

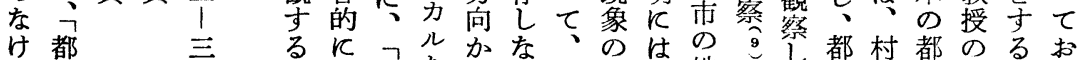
れ市貢と充あならとそど主地しし都禁都のる お

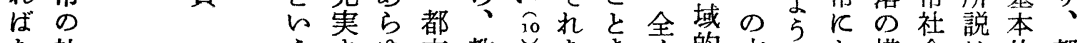
な社 5 さゆ市教じををく的方とお構会は的都 ら会一れる生授と生は反構向力け成学孔な市 な調つる人活反主態子対成へめる原者村態の ら查 の論間のよ張学人ををとして理飞落度社 ᄂ で

とは

的個

見 偏理関ᄀつ守的々表扱抽つ人が\& 向的係空てるプの明々象つと無全関あ過 を過を間論。口はすな娄、人関全吉ら程 指程一的じしセつるがるっと係生るわを 摘をつ秩らかスきのらを必のでき知しそ

は反とと事を5のソあい説果思エつがし

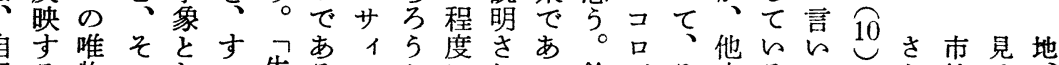
己る物のしべ生るエか加れつ鈴ジそ方るかから社る

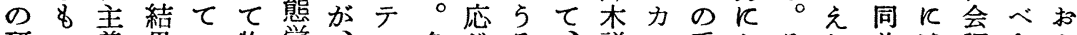
研の義果の物学、1多じる、説儿重おそれ前述調きょ

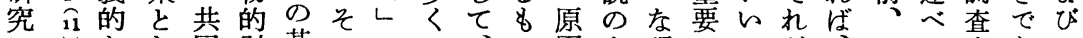
Kしなし同財基ののの、の因よ現でてが、三て方あ、 とと観て体と本点理場唯でで

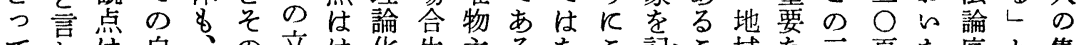
てわは自っの立は化生主るなと記と域な言頁た序と集 生ね然そ過場つの態義とくれ述と的現者説々落

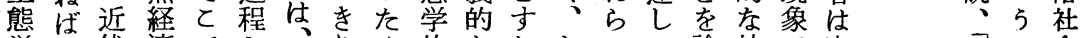
学な代済でと、らめ的なれしのて論社で空 がら社的はし自とにな生ばた現い証会あ閒 どな会な本て然確は説態、が象るす分る的 の々飞分質取的定明学社っはにる化以な

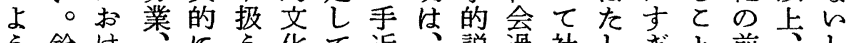
5 鈴け、K5化て近、説過社しぎと前、し な李る㚬生と的お加近明程会かな提重地 位教物衡物と環かな代がの過飞いく条視域 置授神関学で境な軽都入論程論と、件す的 をを的係的あ要け便市り理の理と笚にる現 占除思となり素れなの込が分的乃质つの象 めけ考に闘、とば解ごむ確析にに地い\&を

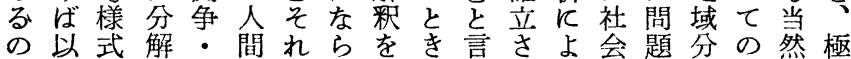
か上をさ共的らな提 との忠れ在社のら供、度てて程あな察はて ら論寒る関会関と寺スらいののるいにあ重 う者に係的係思る・でなみ結としょる視

都思 会

橥考会

問炎埽

題支㷌

四占関

五机係

五的壮

五。住

乙へ居

れ 鈴を

几木第

つ教 一

的授義

$\tau$ 、的

は都に 
らと人の人去にっで構村

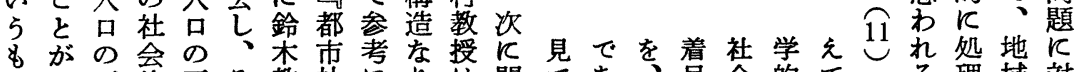

ので正的正そ教社火りは問てあ眘会的て る理域対

のを常機常の授会な、題よる生しの偏打批のさ分し

る生構生あは学る機そと的限態て動向を稿でれ华て

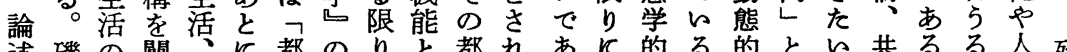
述磯の蘭都のりと都れあ反的る的とに共るる人殆 の村概明及残市大飞密市了ろ観点把評と同。か品 内教念守びるの半於接のの、5 的点で握さと体と流無

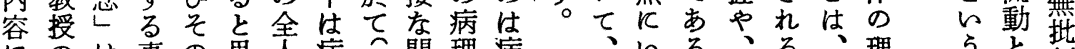
にのは事の思人病12関理病、、るる、る、理 5 々判

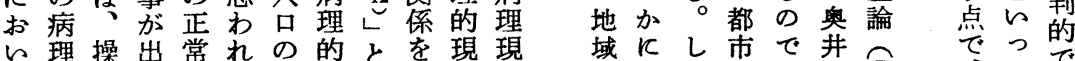

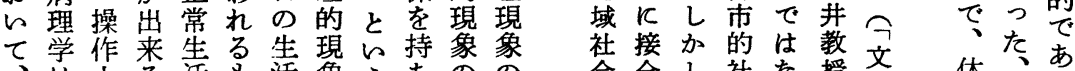
、上る活8活象 5 ち 病、のと隹のの限、把 会合、社な授文华傃々る 理そ便考々に中記定そつ握 現の宜えれつか述をのてに 象限とたにらら反探来つ の定し 13 基て異あけ求たい 構句て 。分常ててがるて 造に充しら析人らで都原で 的お分教てし口れは市因あ 把らと授営たとてああのがる 握てれの亦異いる本、が は正を所れら常るが質都

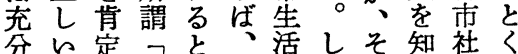
でと步と正をかのる会に なはる常ろ常除る著上の磯

生る経留か自二 性わ 態か済係と号三索ばは 学々現の述の方失形遺 的的象類都三 5 態憾 解 5 な型、都市 $飞$ 的で 釈点りまま論。到現あ を付社たた䛸と学る。

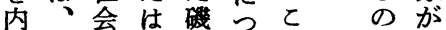
包々心意村々ででいそ すす理識教て若はかの るれ現の授、午なに結 \& \& 像構 \& ᄀ言 々社果 の不な造都経々加会と と明り市済そ学し

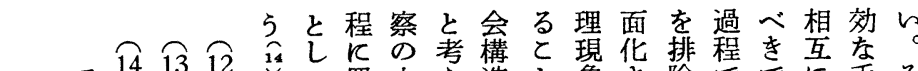

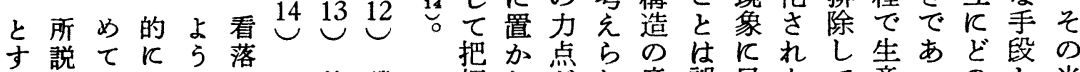
把点らのは的生あど段の

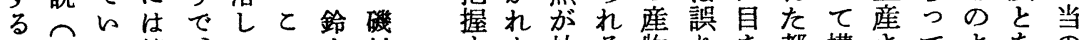
生近る統、てと条村导た社る物りを都構さてななな 活代よ一都的栄英るた会のでで奪市成れ、るる構 㙝都 万を市る私太- とめ構であはわ像しる異にに造 同市 $氏$ \& 社とが郎、 体の思っ会々指、前 の構わたが 5 摘前揭 統造れ生かがし揭書 が論る咶るれ危書 が論し 協る 氐ど 異社し体相必要面 常会てでをず問五 な学 つあ\&し題頁 る 評 前. るつ \& $反$ 以 与論提とと看つ下 のடのの落 と三を前わして の○強提いてて 構号調 K、て 造しす立乎る 的はるつ、わ 関、傤てなけが 連そ村、おでと 凡の教論、はの お前授を実な点 い提の進質いを とで造あっあれでたの常関相的 をあでつてるるは都で人連違把 看りはて、け余な市は口しな握 過、な、正れりか社なっていの 乙まく教常ど、っ会い例い。た たたて授な都たはかえるしめ 結都個がる、市か、とばかかに 果市人両的气生と考失としは でをの者のの活思しえ業い一 あ現住をと異をわろるしら般む

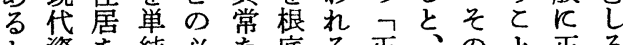
と資を純必な底る正、のと正ろ 言本中 $k$ 然るづの常鈴。は常正 わ主心峻的母けでし木李の、生常 ね義と別なのてあの漖がそ活生 ばのしし関もいる方授、れと活 な構た去連、る。向が自異の ら造消亏反実秩た $た$ 異正身常概 な体費た立は序し歪常常問生念 々制生のっ都をか曲なし題活が での活はて市無にしる生ととよ あ一の的の視、病を活さがり 万環過考る社寺病一ののる、有 
とにさ奈に5教的れる義8をれとじの様

が表れ良位。授・る。のの研らして社式と

で現れ市置第の空結し諸で究のて百会にのさ題社そて

きさ諸のづーと間合た社あし間、科現よよせは会の在

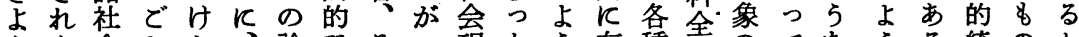

5 た会々ら、論秩そつ現た 5 存種書のてな 5 る 統のと

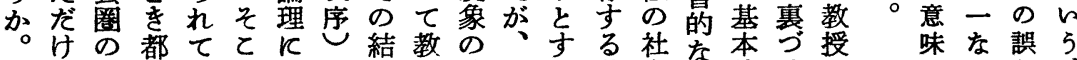

たで地市いにおと果授共そる基会字的けの

し域となはとととは通の点本現のなら論

加充的恬的て 5 乙 的主。的象で組机点

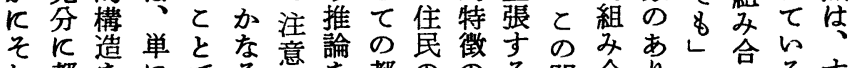

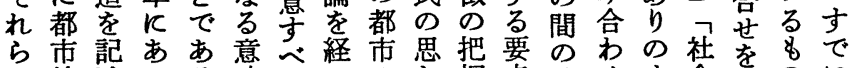

の社述のる味をてのわ握点論せま会明のに

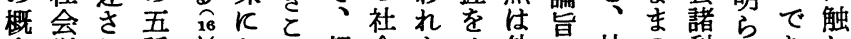
念学れ種。お都会ため外恃社の科市市れ

的为例々在市的意さ延会姿学飞る。

よ反ま都えて社統园す的私関飞のすを

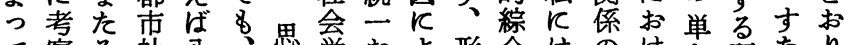

て察之社入思学おな形合はのけ尔なり

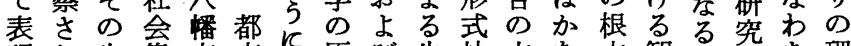

現れ生集市市飞原び生社立な本観絰で管理

さた活団のの次理生活会場り的察会レラ解

れと構ので類の至活学理なん合あ社社

る言造存と型豆構構との解構よ的会会

ごらを在を論点想造と水々し造うなて学学

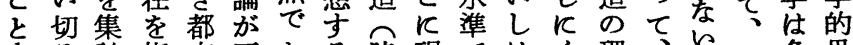

るる計指市正ある時現ではく理、只各思

事と的摘と当万。間わあ広々会そレ断種惟

でる

例念之授

の $\lessdot の$ 自

結、㒭 身

合 そ解 の

上のと見

位原は解

説因、前

めあそ述

ぐるら

る

新 5 協柔

明 $K$ 同盾

- み体要

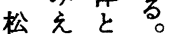

本る論 そて そ

諍 汃の

をか地前

想 る 域前

市在提味正各置さ関んもつな授れののつ的問でで此態

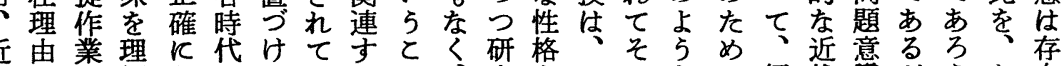
代がな解理あるおると、究を日となの経代識が5あ在

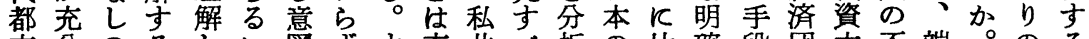
市分のるしい圂ずす充共へ析の比確段団本不端。のる と理都。、はが、な分がをす都較なと体主明的都をで 解市そそ各みしわ反ととる市の問しと義確に市まあ

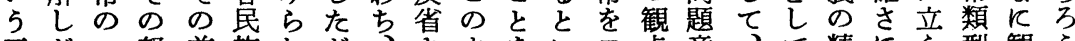
三が一努前族れが、さををん点意门て精に充型観ら うた般力提になっ都れら提 51 筍都の神由住論察か の 論がのよとて市ねな唱視口らが市都が来、のし

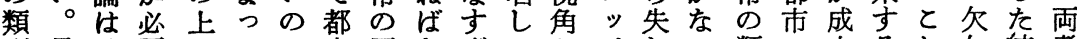
型具要でてで市歴なぐてかパわい類の立るれ如結者 化体第で、異あを史られいら都れ限型団す。はは果の は的一あそなる全的なてる市るり論体るか都奥と糜 必点るれる。体ない社が市とに、を精たつ市井し業

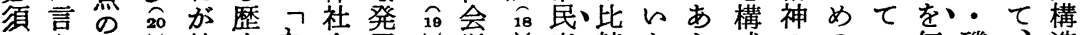
の 5 指し持史わ会展。学意較たら成ののマ何磯、造

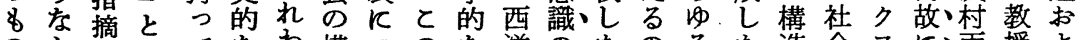
のら泉てなわ構つのな洋のたのるた造会スに耐授よ でばと 5 い形れ造いて問史存上で都もを的・採教のび あ 的とる成飞体てと題家在であ市の問基ウり授原政

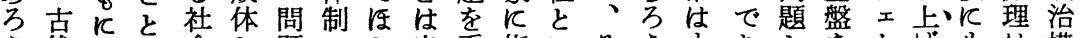
5 代艺会と題のと当看指らそ5すあとを、げ、すは構

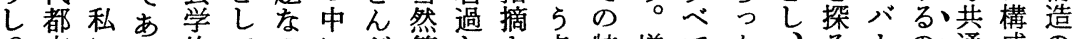
21 市飞る的てのにど第しさ点特增てた、る

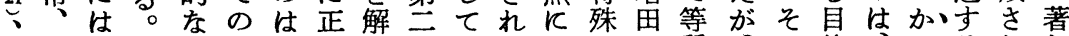
近封そと真都、当明のをる注日四質 17 の的、とるれし

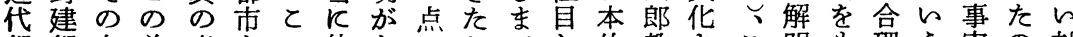
都都存前意をの位な苂とでし的教さと明す理 5 実の対 
よが組てな成かの把り代ぐいは的ま度ての本的な国市

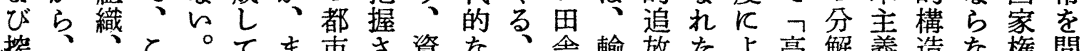
搾、て。てを市さ資な舎輸放たよ高解義造な権問 取三情れのいたのれ本都諸の出に利が社のい力題 関者義をみる諸把得主市特諸港よと、貸前会地でのと 係相組市なの種握な義は権地飞っれ都と者の域あ存方 が互織民らかのはい経、都点、てら市商の経的ろ在る

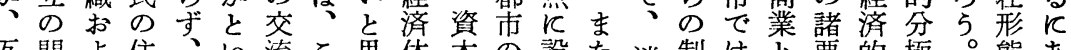
互関よ售、々流と思体本の設た消制はと要的極。態 に係び居教 5 がのわ制の激定旧失限ツに素棈とわのた ら、闑に授点互よれと原しさ来しはンよを造しれ地つ

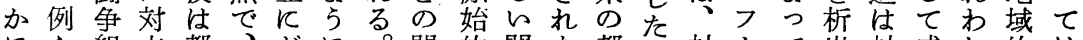
に六組立都它に。関的闘た都。封卜て出封成れ的は 必ば織す市平の考鈴連蓄争。市加建制形し建立はな

然そのるの面よ方李積をそお家に成た社しま結近

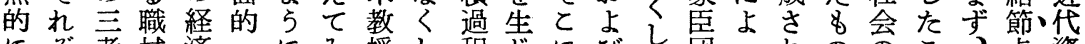
にぞ者域済・友授し程じにびし団うれののと、点資 構れのと的羅しるのてのたと都てのてたで経と特と本 造給統し集列てと、吉二のれ市解、貨あ済を殊し主 化写元て団的近、社、環でらの新体そ幣る的念近て義 さ体ととをで代何会近とあ新ツた、の資公構岕頭代、経 れ秀しら問あ都が的代しるしン農産本等造に都々済

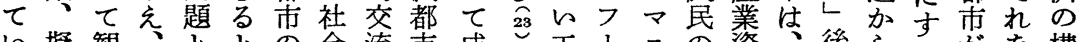
ら擬観ととの会流市成。エトニの資、後らへがを構 る制繁職・言社的のの立し業の二収本農者現き資把造 か的さ域るわ会に結本守つの統フ奪へ村のわ集本握な 飞家れ集にれ的交節質るま培制了おので内れあ主しら

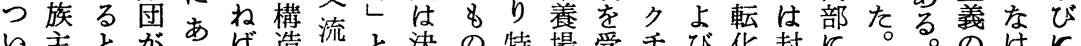
ら主とがあば造流と決の特場受于び化封に。すのけに て義し職たなをすししで殊をけ部を建お後つ経れ近 述おな務っら構るててあ近めなア分阻制的者資済壮代

てがるとっ団点にカ解るとがの的観のなある解のをん゙

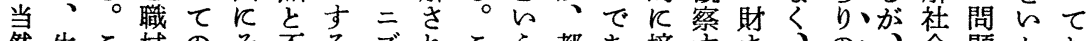
然生と域のそ不るズれと5都あ接守を、の、会題かお

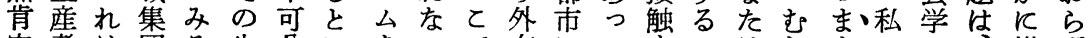

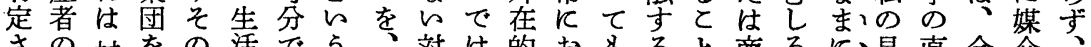
さの村をの活で5、対は的お活ると商ろに見直合介 れ生落中存の手そ象理なけ名架広、地接理しま る産の軸在殆る段れ範解条る単ら要を義人加的的てた で手構とがん。とっ囲社件人な求媒の間ら対ない職 あ段造し持.どすし理の会な間るたさ留あ関す象行る域 ろかとて続全なて解奏学々関人とれとら係る外為か集 5 ○の構さ部わ役さ質的し㑰間充るしゆと都飞のと団

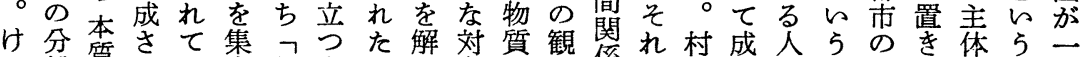
れ離質れい市都\&社明象的察係が落立間矮枢去と基個

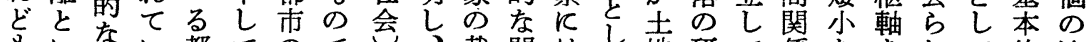

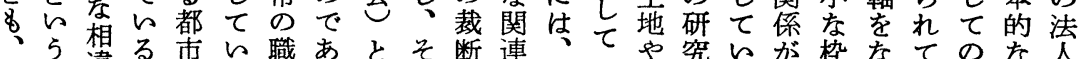

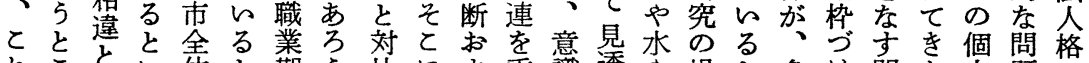

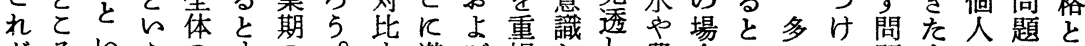

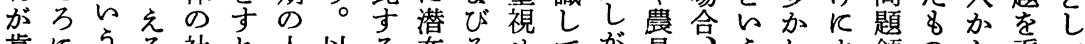
肯に5 る社れ人以る在々せてが具只 5 れょ領のら看て

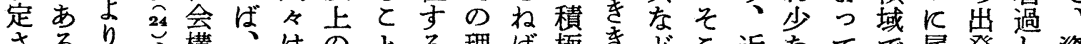
さるら、構、はるとる理ば極きどこ近なで属発し資

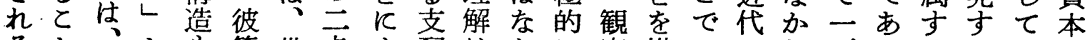
るとと等世点よ配はらに察媒のの热面っるるると

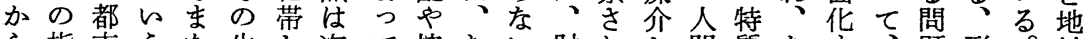
ら指市 5 た生と次て搾むん財れと間質なす、題形。域

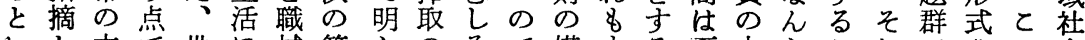
的本で世に域第らのろで媒する面中らてれで川の会 つし質あ帯よ集主かメ理あ介る接でかとを埋種と 


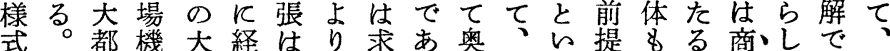

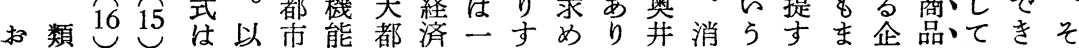
り型都上のの市学态るら、教費一るた業と消ぬの 論も鈴市の論重論的納都れ現授生方。そ体し、費と一 結 $儿$ つ社三究要反偏得市ぬ代飞活向職れのて、生と方 節類と栄会う飞性関向で研事都よのに域自営の、活乃の の似多太ののおを古がを究と市れ方抽と身利職飞でみ 意の鈴郎研事々指る指るの索及ば向象い一事場限あへ 味構木、究情て摘限摘\&第るび に导 5 つ業生らる世 す想教前にを実すりさの一无現偏る概のへ活れ。帯 るを授揭と考質るはれで位との代向と念行のにる市し

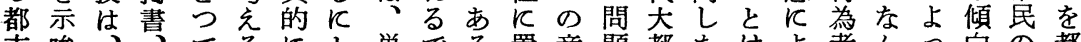

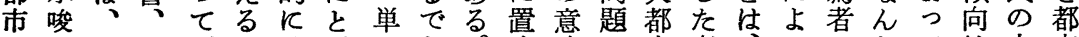
にし社一不とはどにあ。く味の市直、っとらては人市

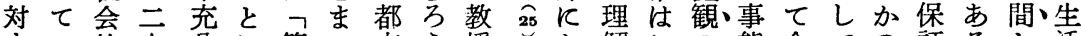
すい的丁分反等っ市う授し扔解ての態企ての証ると、活 るる交三でよ外て経令はべいはの結の業都参さがしい 質が流頁あっしお済し自をて、経果あ体市加れ、て基 的、のるてにり学とらで経と済なりの生をたとの本 な専結と放、の述フあ済の関のの意活前、の生と 意ら節判私逐第、研公私る理根係でま味飞提そ人活想 義量機断はさ一究てのす論本のあまを参すの間は定 K的関せ理れ位問ら場奥を的裡ろの職加る裏と右接 触なのざ解ての、題る合并的飞5 考域しと面しのる れ基配る社に経をけと教あ束成。察内てとでて都の て準置を会る済列れは授らを立てでのいもあの市は

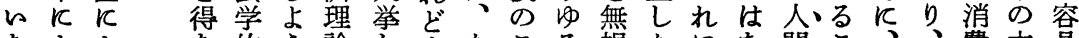

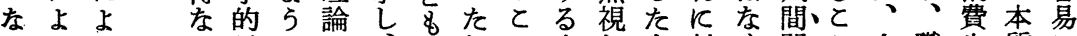

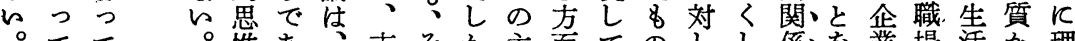
○て。惟あ市そか主面てのしし係を業場活公理

す力枠ると若批と学

る K、と。体弁判と的私

よ。すし制のはを説は

○っるた的蛇ほ指明都文

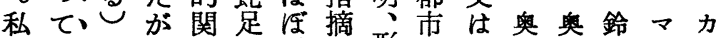

の裏をつ連を妥し形社多开并杰ル1

対打、てお加当え式会く、復栄ク ル

象ち現私占艺た理学の都太太飞・

とさ、段はひ告あと解に示市郎郎、、

寸れ、階、経私り思社み唆研、同儿

るた、に、済見、5念らを究前前前ク

都階小般団を病。学机含の揭揭不

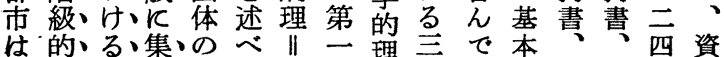

さ支資落、処六異の解 亏 $b$ 的一一章本

し配本、理理常生を䒜をる課一四諭

あの主いらを解現熊と特と題九

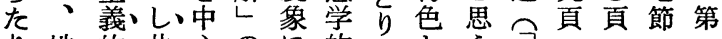

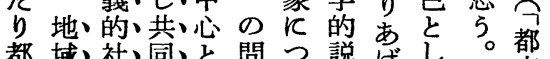

都域、社、同々閣つ説げし 。都

市的、会、体し題に明、て、問

般存、制当考つは注つゔ生題

で在の面えら鈴的態四

は形、な、てて木て \& 学

な態かか地みは教は修的

くと、で方た都授鈴 正説

てし、自わ市の杰を明

近て、国、治け類 反教 要

五

代把、家、体で型論授尔病

都握、権、をあ論飞のる理

五

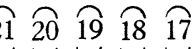

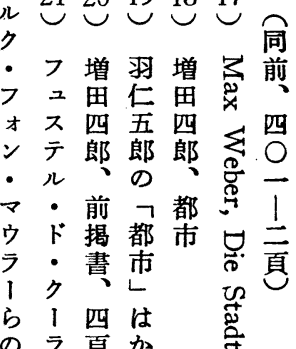

の頁か 守

都ン尔 こ

市ジ る う

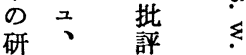


然をさ II 段一の市握層とにい究政市い5社るをり理市 性なれ政階しでのしの思媒か导治がるか会広規、川で はすて治の性あ社、利 5 介にる機近と。学義定ま異あ ての意資のつ会ま益。し関場構代言村者の先た常り てでる識本奏て過だ近て連合が的わ落が全る市生、 Кあ、の主質、程は対代にし都間\&民活都 ある日一義がとは把立のるて前りあて研市関ののま市 る 28 本定経明れ握し都かお述のる、究の係と消たの ○のの済らら経につ市、りのすを素に政をし費は生 都全成の加の済失つにと、問ま信直さ治すて中健態

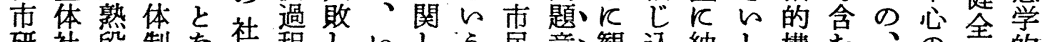

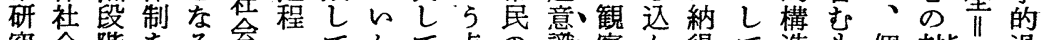
究会階をる侖・てかて点の識察ん得て造も個対步過

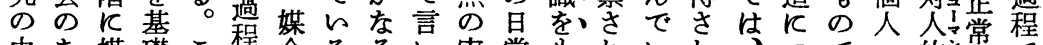

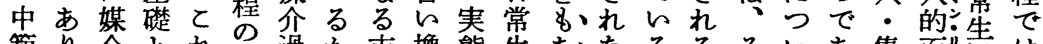
範り介とれ過か市換態生ちなるるそいあ集面活は

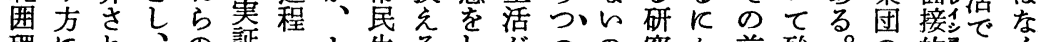

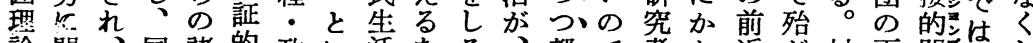
論関、国諸的政ら活なる、都で者か近ど村両関は を連あ民過研治 5 過らと都市あにわ代発落者係なて

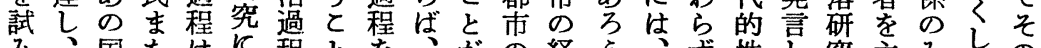
み、国たは程とを怔の経 5 夺性し究主みして よあ家は、よのに媒独基経済。都、格な者体でて社 5 り権そ言っ三な介占本済に私市都がい反とは現会 と方力の

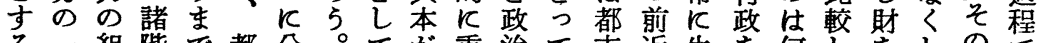
る一組階で都分。てが重治て市近生を何しをしので 二構織級8市析つ市市要々、社代活把故飞媒て 8 あ つ成にのなのさ政民でを政会的し握で、等、のり の部集社く烏諸あら治を? ?て都とそで、 必分䄪会現統る都把階るかが研异都てろ市すれあ病

完概調上は観後が市事そ論し村注 都全況查怘の、它実れすて合意以 市を。集旧ると低戦のではる新併し上 の期沿計市が新市後的あ所と市、促な反 分し革結飞、市はの八る謂と形進けの 類が果視とと著市割。新は成法れべ をた基へ野と、での明市てのしばた すいゔ人をでそくは告がて䒠のなと るとく品は限はのての些行で態評らと 方と\&構る慣ら従のが三政は研価なろ 法はの成と例づ来比第年都差究のいを と遺で.ととれの率第以市控反問の基

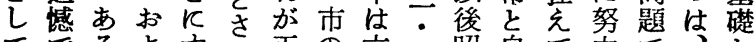
てでるよすれ正の六三昭自て力で、と あがびるて当観割次和然おしあ昭し

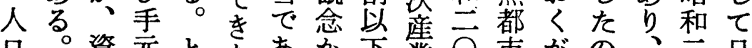
口。资元とた市市業官市がの、旦

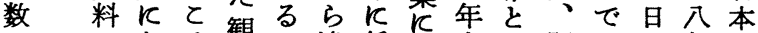
にのあろ隼会逸低徉まの関あ本年の

上制るで念と脱下徒で甚連つの都

っ 的市、K て 加以勢以従 5 た 方市しあ。会月を 大号要下、論市とるととる町学飞観 ・市覧は、議がく世芯ズ点村者施察 中. - 性の和た、増とにたを略併とをる 小格他三資極しの属女示記飞机々 と のK五料めた法しのししつをたあ

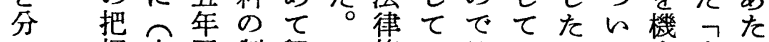

つ握市国制興と施いは和的て会市っ

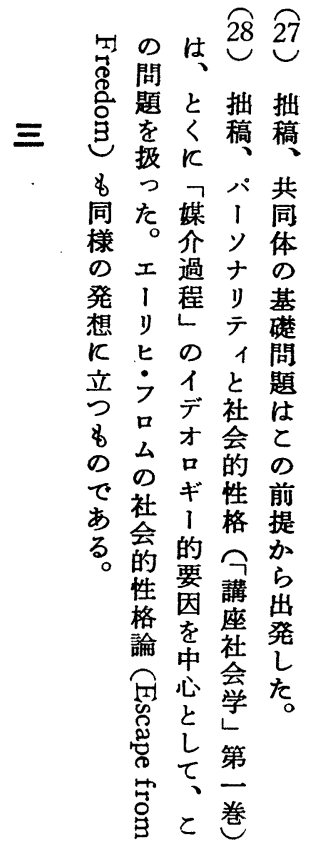


お

的右

てにす市查飞間人とにが五生 29 レ六\%下産っ万とると

8分る的結示隆工 $K$ 採三・市

29 づ 以以業ての三たが

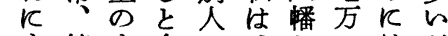

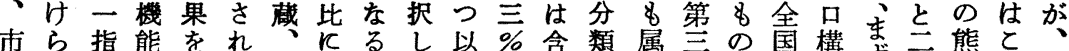

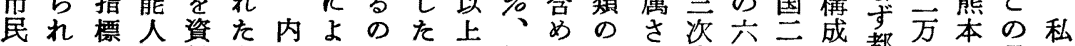
のたを古料方山つでのの第る基な産○西に都七と量見 社四示しと法和て、で類三さ準い業市八ょ市市は的に 会つ唆をし $飞$ 両都分あ型次のと中全市っのの分よ II $ら$ 産て教氏市類る反五平し間口第のて社相社類れ

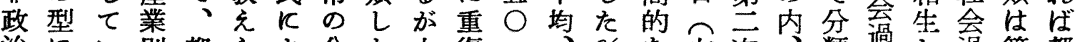

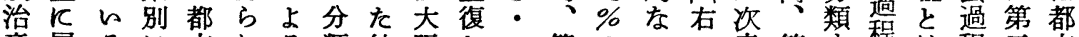
意属る飞市れる類結阪し一第のんの産第梦程は程云市 識す。算人た在果市て\%数し他業一る性かて義の Kる今定口。人行の属を次字混の人次と性なお的社

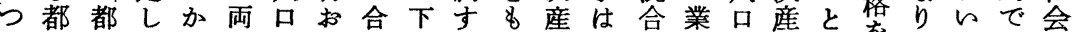
ら市市てら氏から計松ると業、的種業がをのてあ過

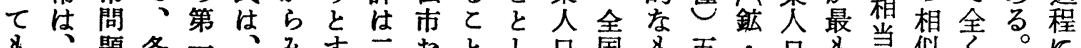

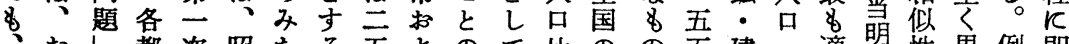
おし都次昭たる五よのて比のの五建へ適明性異例即

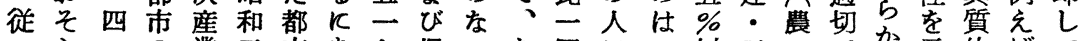
っ二の業三市あと児らな四口七以工・で市示的ばて

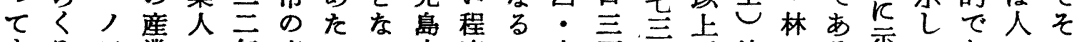
まと三業口年産っっ市度べ六方市五比・尔てあ品の

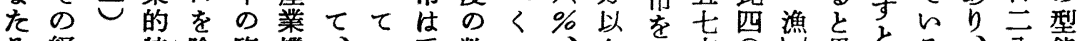
そ経. 特除臨機、々重数一、上数市 0 㥁思る、公態 の済色々時能私る復值つ第の充と\%比 5 忽。逆万を

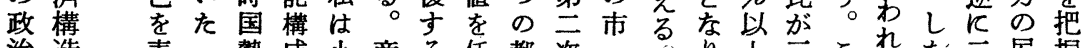

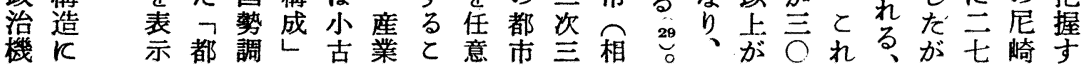

にた本料せ住を明程り仁の形さる 的さ日範型に市構 ○加のの更治の、五主態れのとにれ本囲のとは8 乙、利労し 地飞維性ま郎要反てでと、るのを特れ互互

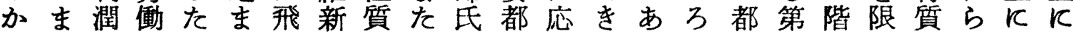
したを力のた躍とか比の市代たるで市三級定をの何か な無保なではさそら較所はてもが第研次構す把全程な が無証らあ二世れ、的謂大質の、究産成る握部かり ら年しっ寒飞西新䚴部的でと次に業ととしを社特 I山る交た村あ続欧し市分にあれ産お型地とて問会徴

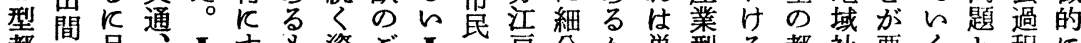
都地足、I す資どI の爷か単型る都社要くと程に 市毞る市型ぎの本と型都時守らに都中市会求とすの異 があ立場都なを主を都䒾代る、第市範でとさとる近な

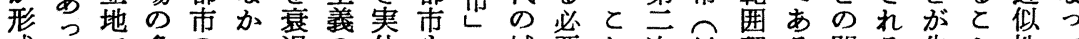
成たで条のっ退の体名て城要れ次以理る関る先と性て

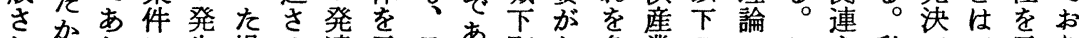

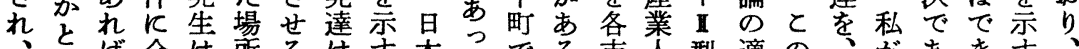

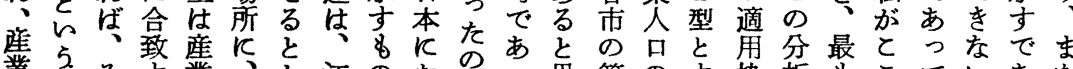

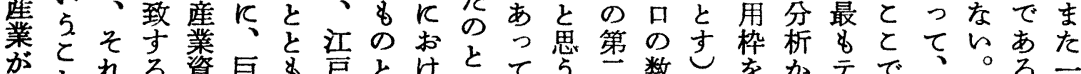

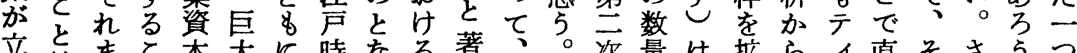

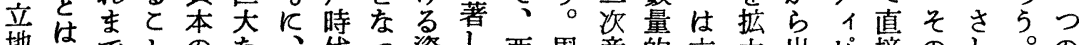

地はでとのな、代っ資し西周産的六大出ピ接のし。の

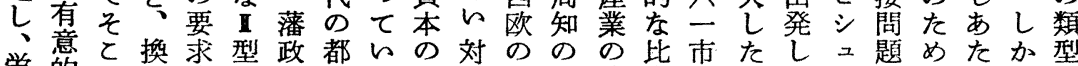
㿥的が言守都期市な原称中と成率のいて飞飞飞っし飞

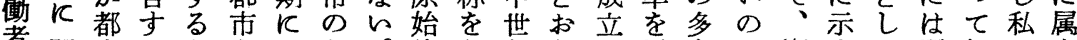
者関市れ主をおあ。的な都り立以をで漸すた更個はす 集連でば!出いるし蓄し市、存て反あ次とい反個今る

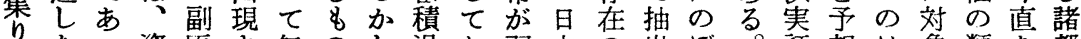
りなっ資原さ無のし過お羽本の出政。証想は象類古都 


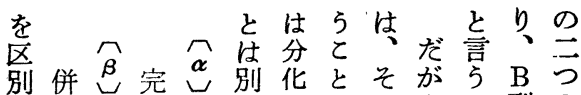
寸存全交等の

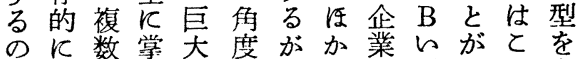
で参の握工只、以体ずでれ考

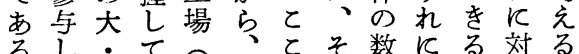

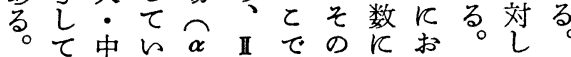

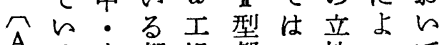
孚る小都場都採地って 型の市と市上時て

応ま浜は根都

純

粋 A

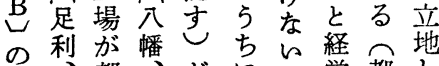

区都界范で営都し

別三市苫一沶市布

と条の 小個

小容反座

$\tilde{\alpha}$ 岡済牧あ

○に企業

谷過秩

$\hat{\beta}$ 堺程父等 都

つっ業 が

まて势市

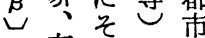

b \& $6 r$

の布れ

私、<対

区施沓経

は地つし

別浜競過

A 域あて

近在

代 封

的建

度都

方

発 之

生 近

帒

I 市

$\mathrm{B}$ と る

の松竟過

ののかつ

型 と

都 の

市合

区関と意あで

組等

を別連々義

るあ

がを

\begin{tabular}{|c|c|c|}
\hline 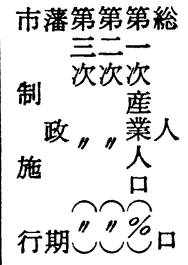 & \multicolumn{2}{|c|}{$\begin{array}{l}\text { 市 } \\
\text { 名 }\end{array}$} \\
\hline 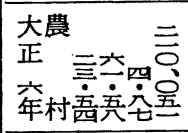 & 八 & $\widehat{\widehat{A}}$ \\
\hline 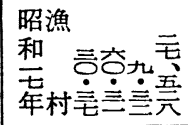 & 生 & 型 \\
\hline $\begin{array}{l}\text { 大城 } \\
\text { 正下园五无 } \\
\text { 吾 } \\
\text { 年町至元空元 }\end{array}$ & 崎 & $\widehat{\widehat{B}}$ \\
\hline 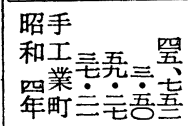 & 戸 & 型 \\
\hline
\end{tabular}

る。 $\begin{gathered}31 \\ \text { 型 }\end{gathered}$

忞桐川藩市て市る甀 治生口政の、でK。 夕維等、期 5 加あ至如 張新し川反ちなっっ楽 、以崎すにりたた機 新後、で質か場関 浜は根都《年設

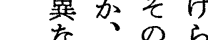
野七河形全都れ 田都態たく市 市敦を哲新の学 苫的賀示 のし社校 小形的会 牧態名て な過保 古的集程安 相示屋た 罜住吉行 飞四型わにと政 釜々日都的よのが 石た市市るる都次 る 八I 米尼従のがに 幡型沢崎 つ潘都 都、てど政市 日市桑瀬私与期を は両れ高類 $\boldsymbol{\beta}$ 仮市 3 理東 $\mathrm{A}$ 思具市

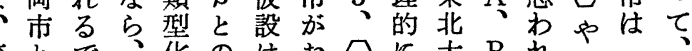

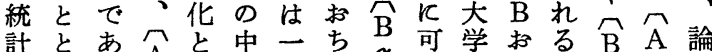
計

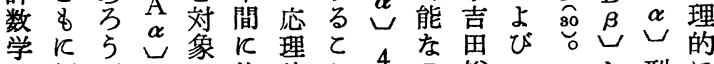

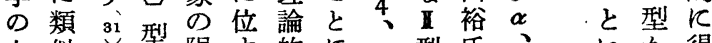
上似。型限卞的 $儿$ 型氏、

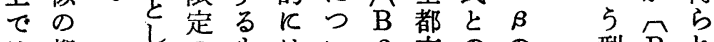
は都での名はい市市のの型 B れ 全市。任手の説て山討基は崖る くを、注続の明はの類議準特し類

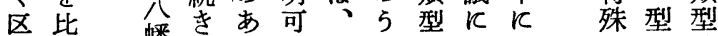
別較幡反る能私ちとなっでかは です市従とでの、しうい方のの四 るるうと資現ててててるいつ

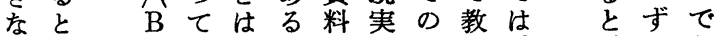

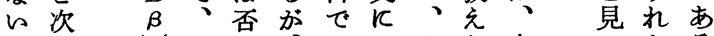

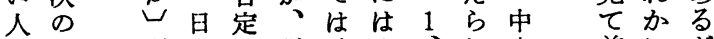
口上型本し詳確 1 、れ央差飞が

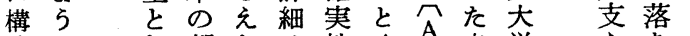
成飞都なは性 4 A 点学充古具

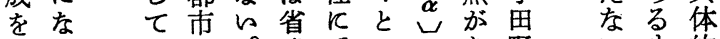

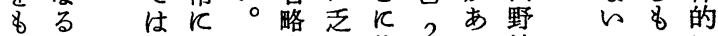
つ。尼具扎集2、る崎ののに て 崎体るら中㖵昭でがみ

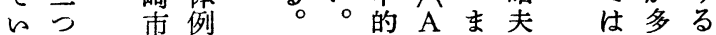


てと実にり場中運のはとのが業しるまいはずっ造

みの行結、 $飞:$ 輸六全現産、部た卜形 $\alpha$ 号の以 よょさば市強小・割市わ業概第そ分他の態工特下

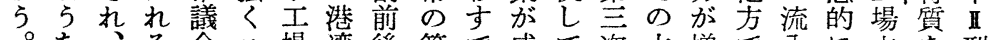
な、る会依場湾後第で成て次大堌で入に立を型 公財市は存々原 $\alpha$ 次方長工産部加は者は地明都

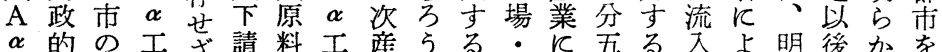

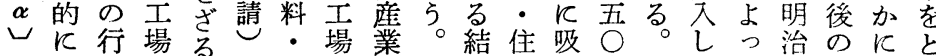

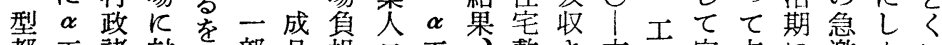
都工諸効得部品担口工整さ六場定占に激たに 市場施す惩ののの場市地れ○設着めおない几

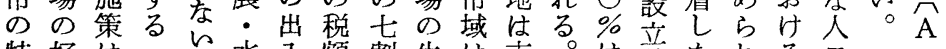

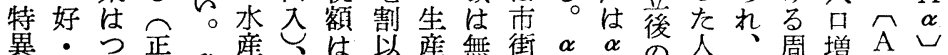
な不ね負工物商市上は計の工只流品以辺加 $\alpha$ 型

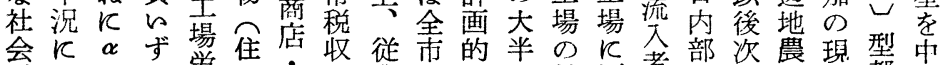

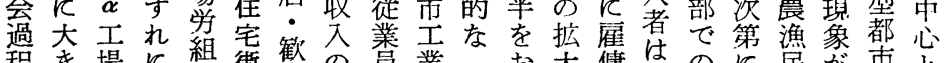

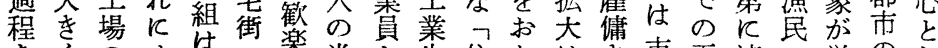

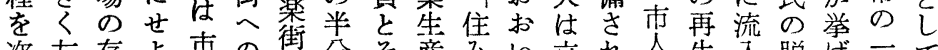
次左存上市の街分々産み的立机人生入脱げ一て 反右在地供公以の分、地、口産人落ら般分 やさを極区給業上家七けそ条残の公只し扎的析

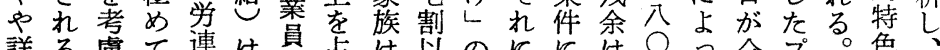

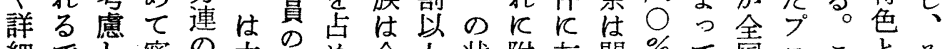

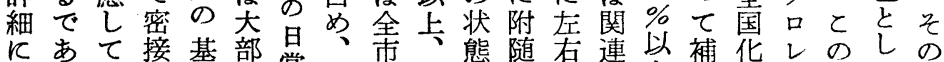

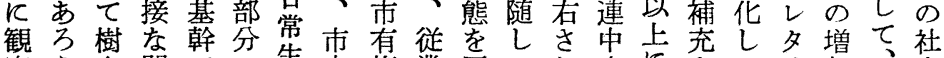
察 5立関で $\boldsymbol{\alpha}$ 生内権業歴てれ小にさつリ加い会 し。․連あ工萿の者賲然他る企達れつ分ま構

は と 5 再

都対、成の四氏ず 32 市立都守图回飞る 共之市る式東よ \& 第 同しのとは北るの一 体て中と財社\&の四 そ把核がの会の流中、 の握た要流学で通

\&垶る求通会、方実 のれ文さをです向線 にる工れ経報でをは おす場る済告に示財 けではで学さ私す。 るあ あ的れと。流 資つ少ろ原たこ通 本て数 5 示と共の方 - 、のしと同図向 経と経つて在研式 罍の嘗ま的究の破 階詨者り る記の構線 学立音とかて打昭告幣 㗢少大方れく和前ま 者くな明を。豆記た 階と賃白社 三思は 級多労で会年野々 と量㗢あ学秋崎れ の的者る的 $の$ 昭 K 対に㟲曾に第夫準
因と本送部と情国人流統

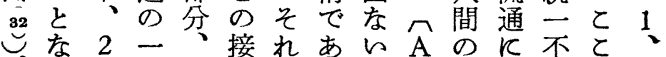

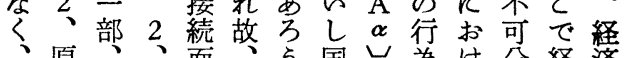
中料 5 学面資 央䊀ひ本 ま 備力き 灰品、出運 は販 3 品動 国売厚市生施式 外市生施と式 流 6 の る 4 税部示 ご と利のっしい 的閏六とたて 5 の $2<5$ 構 各 成側関そに場 み洁苦修 $1 、 ら$ る都考理主な で市ら土放

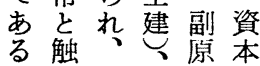
第合 $1 、 4$ 料 と 一 5 資輸小市
5 国山為け分経済 際型関る $儿$ 済過 的都連、絡過程 規市を財 み程 模 の指 の 合と \&済てレて5 つ過いは いの 白程る。゙る 大を。广社、 点定渦実 資守程的 本る のか反 の基 側らは 構本的面分媒 成な抽析、過 部性象的程 分格さに、を では程経 あ $\alpha$ 限佩政 る $\alpha$ 限財 政 ら場 での過 5 㤎年痤程 を経しトつ 


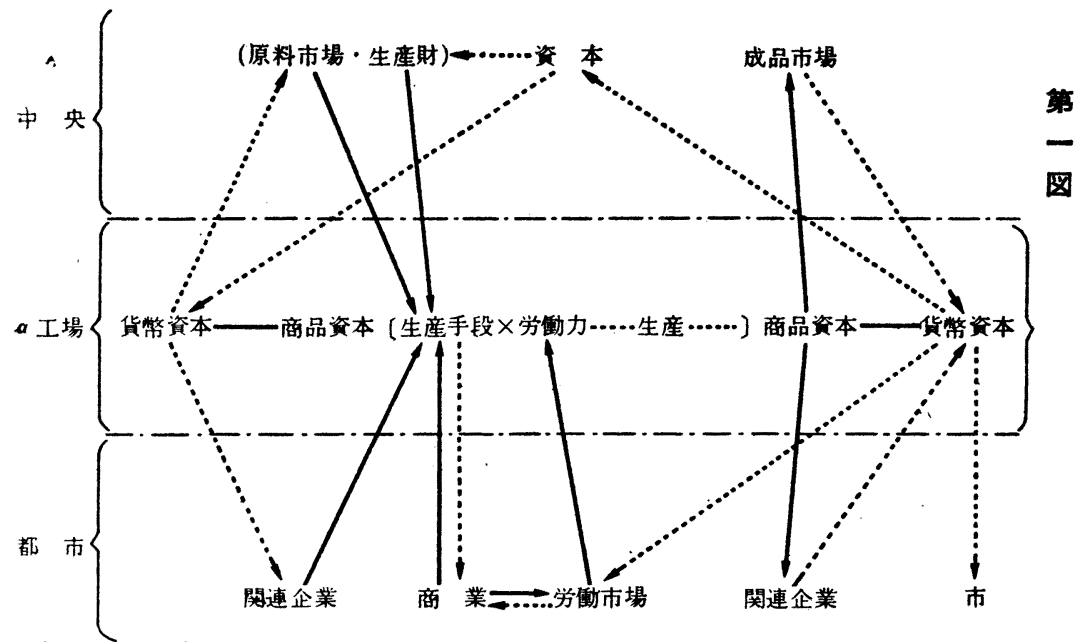

心市あ本社はるは中基造人相8労入公例成み元抗 的のつ的会八等々、鉒幹船口生働蟠蟠えを階しと 分研て範過 A

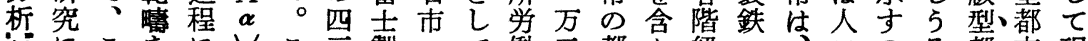

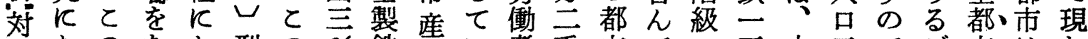
象おのなお型の\%鉄業い者手市でへ五少三でど市はわ

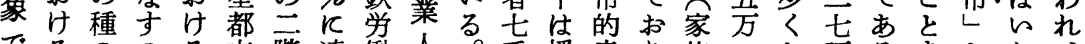

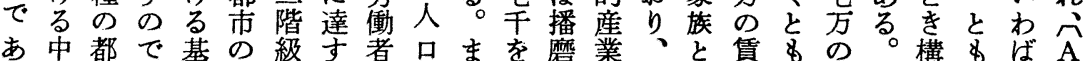

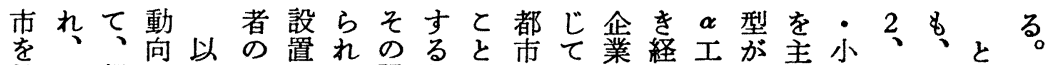

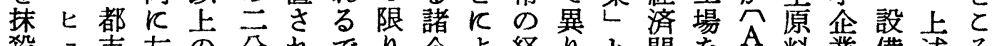
殺二市左の分れで 寸1 と右諸法たあに業つ済、し係中占と群建しで るバのさ社が場ろお群て過まてが心型す設た $\boldsymbol{\alpha}$

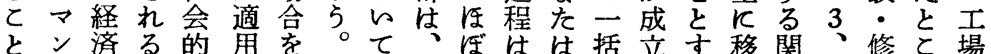
○的。範さ考と、社充公し卞る行連と理ろが あ報関々疇れえと $\boldsymbol{\alpha}$ 会分第れ5ると方産れ・ か仮 り告係れはるるろ工的飞三とるとれる業ら運らり

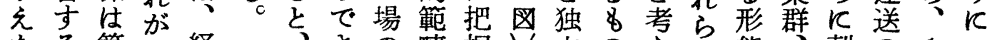
たる第独経、立疇握山立の元の態管刺の 1 無

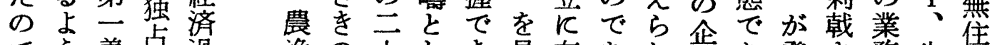
で5義苫過漁の大しき具存あれ業あ発さ務生焦 あ $儿$ 的資程業仮階てる体在るる群る生れお活地

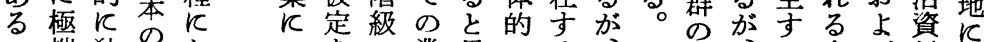

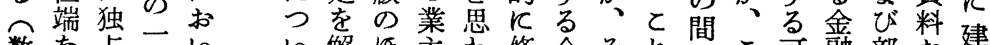
数な点翼々てい解瓜主わ修企それ反と可融部お建

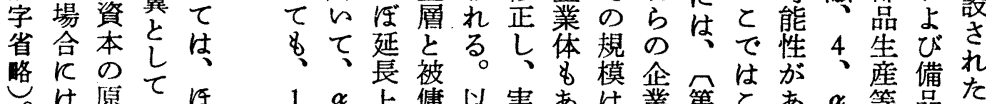

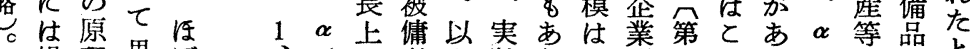

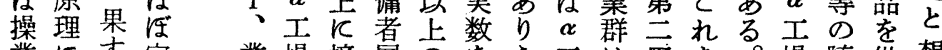

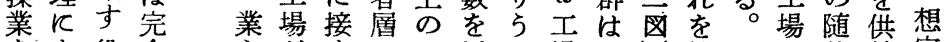

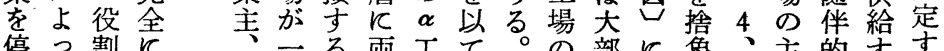

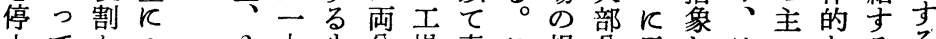

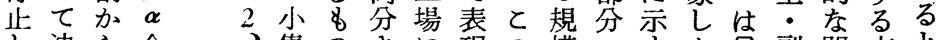

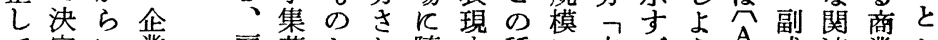

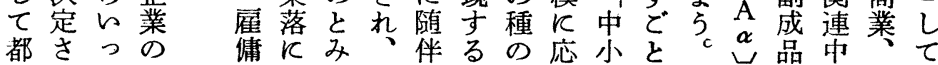




\section{第二図}

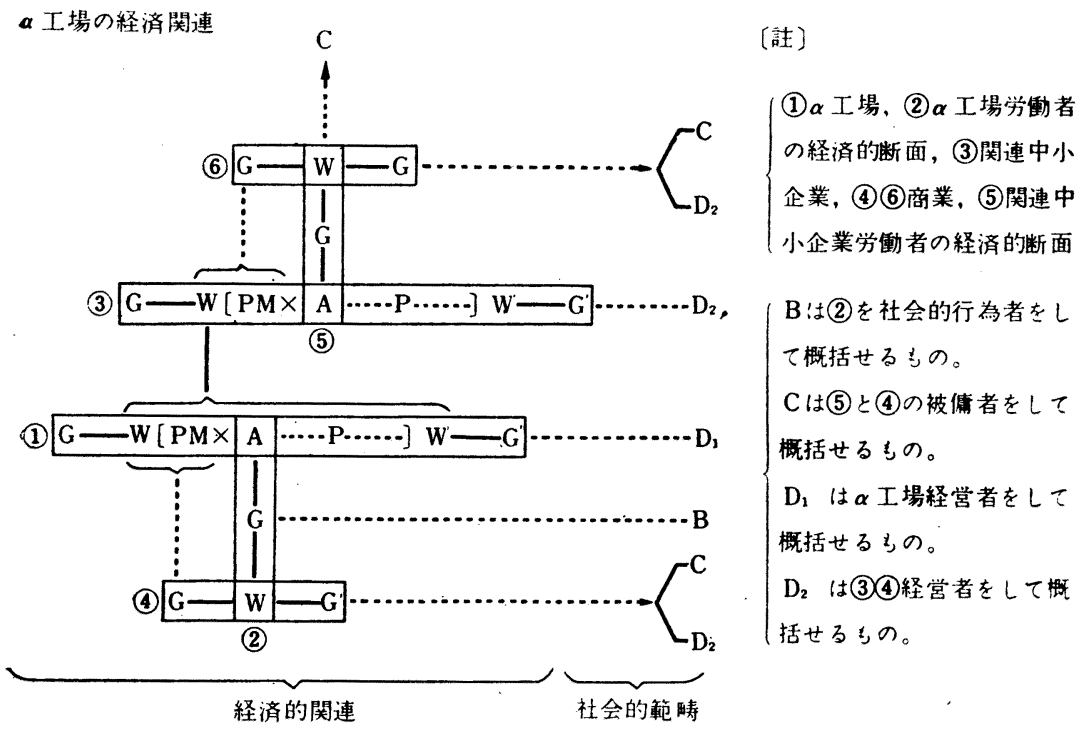

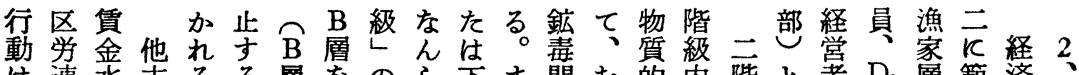

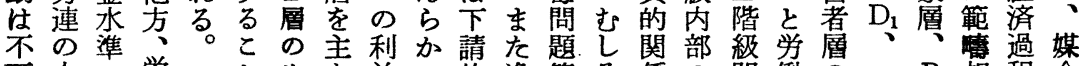
可中学々生应益の的漁等 万係の間働の $\boldsymbol{\alpha}$ B 相程介 能小高働、活る的形企業を $\boldsymbol{\alpha}$ を問の者五企、互の過 で組ら者例欲需連で業指転企安題関階範業 $\alpha$ の分程 あ合 $\mathrm{B}$ 階求要带の導機業ちで係級疇経企利析 ると層級購の者へつと者とは皇業害の のはの買過とと赤転にし基に、者従関結

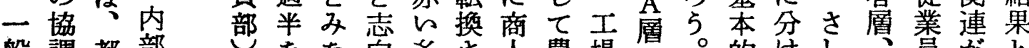

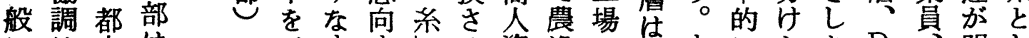

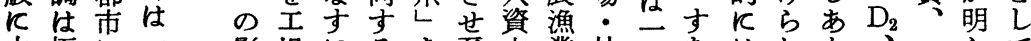

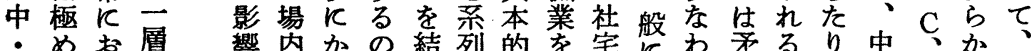

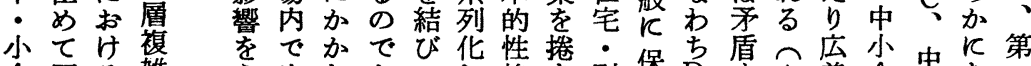

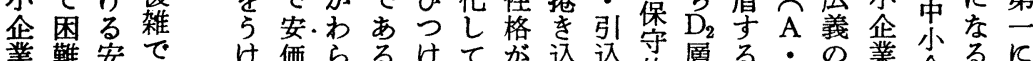

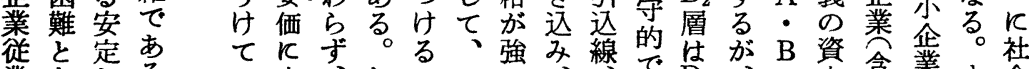
業を定ある て

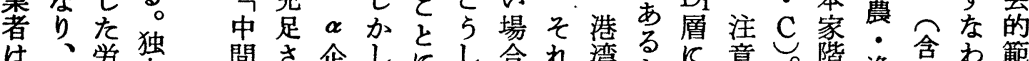
は、労独間さ企しKし合れ湾るに意し階㴔含わ範

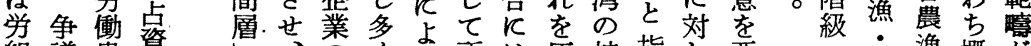
組議貴資以、のく方は压拡指し要 をの族本的貨工のて謂穴倒張摘て守 結さ層を北利幣場場て地そし热さ瓜る

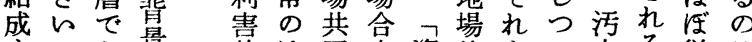
寸にあ景状流同商資的をつ水る従は る る 
市民用万

る足得くは奖数て各 几との和みては対て 民币すす の諸るか导 1属乙的 デ性ととの 才はれべ 口出当飞た ギ身然つ七 1地でいェ は・あてラ 規学乃はル 定歴与個七 さ れ年そのは る 令 の都

。状市々 金性況のの 石等とおま 市し都かま のと市れ意 譋ののた 識 查相七状面 結関工況飞 果のラが投 反如儿極影 女何七ぬさ と原てれ ゔよお大る らっよをの ててびくで るな、C況のい層さブしフ合ら值强す 程々ま層は好るはらにて階組れ接力る極 度かたでみのて互に的A 級織るに告め のら作あらがとにとた。し等懷階職業て \&でるつれ中は分れる $\mathrm{D}_{2}$ は柔級制予不 のあ余てな心注凝ら七尿経よ策対が備安 でる裕、いで目しのエが済つや立あ軍定 あ。\&とだあにて範 ラそ的て、をり的な つ一なれろり值お疇儿れに間社和、地雇 て般いは5、古りをとをは接宅ら家位傭 、下生。多る、日”と対的に早族を条

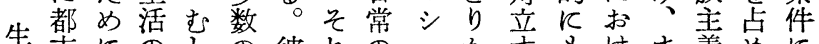
生市にの乙の彼れの二か守\&けま義めに 话の、基ろ集等ぞ集なとる闘るた的るあ

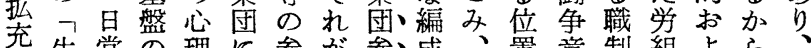
充生常の理反参が参成、置意制組よら、 は活生不的参加一加と $\mathrm{B}$ 亿識の幹びで活 各拡活安飞加寸個のな娄は近部人あ発 家充が定最しるの状っ中る弱隣の間るな 族集最性大て集況て間がめ集労関。運 が団\&との人団擬か現層、ら団務係の動 私上刹、モ格は似らわと現れ化管主みは 的は郡参ビが職力観れし実る、理義な妨 K殆的加リ解場 おどとすテ体にトすの最はす一員諸ずら

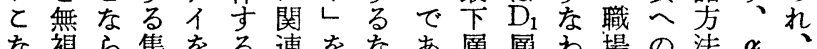

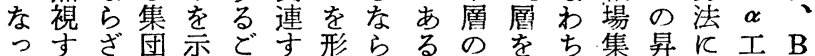
てるるがすとる成ば。C項三団進上場層 らにをなの少し人点うのにった

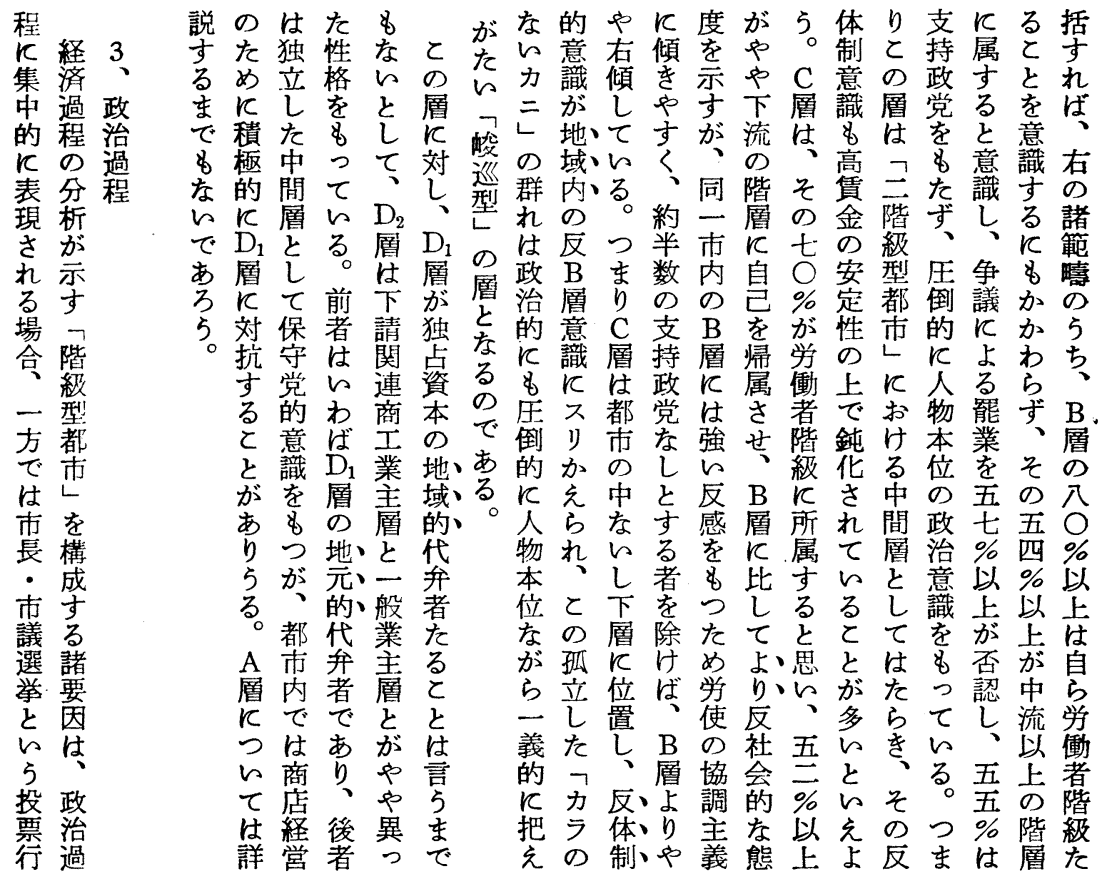


$\mathrm{A}$ 識級後 $\mathrm{D}_{2}$ であ八京存実明多益投会りた方が港た動 - 如型進層ある幡浜在質? 数帒ぜ命とが政前都と政々 B 何都的のる。市: と的し派表ら出しつ治述市と治し

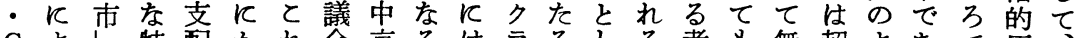
Cよし特配かれ会京るはラるしる者も無超よあで压

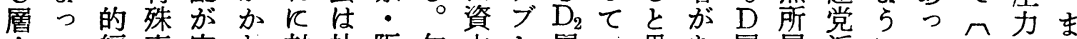

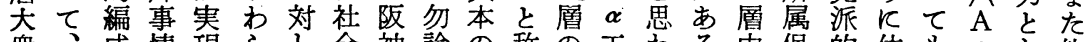

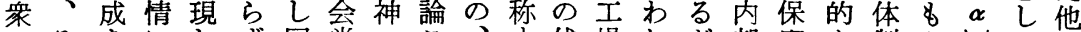
のそを反しす同党・と、代場れが部守た制 A 政の示よて、じ二北の地る表䳸る、の系る的層型観で 治政しるい社 I 五九議元とと務主 $\mathrm{B}$ 交のべでが都察は

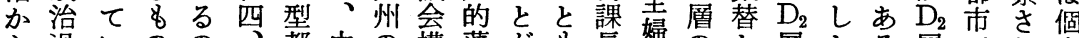

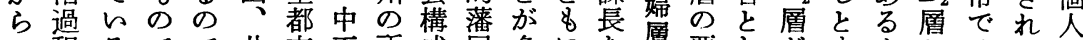

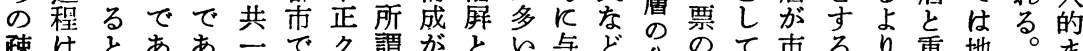
疎はとああ一でク謂がと的ど分のて市るり重地。を 外 $D_{1}$ 己 る

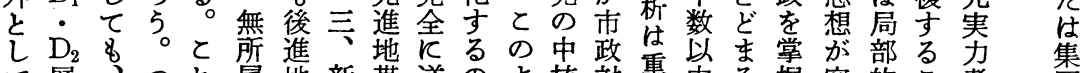

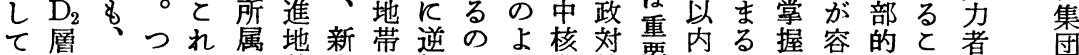

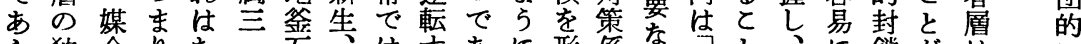

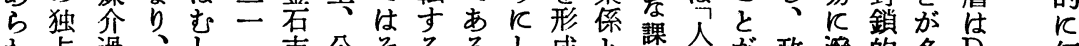

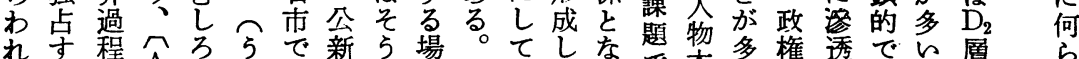

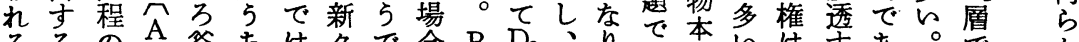

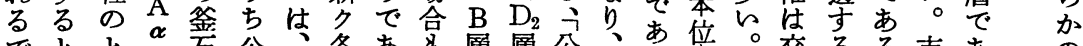

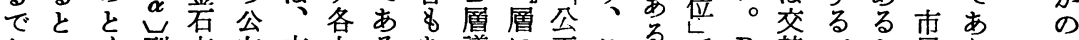

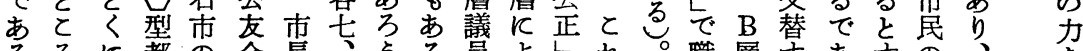

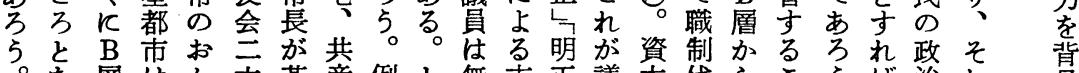
。層は加六革産例と無市正議本代らと5装治れ 景

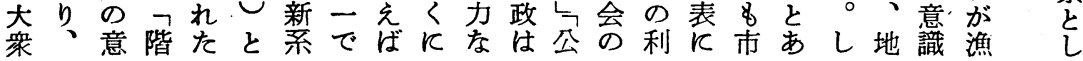

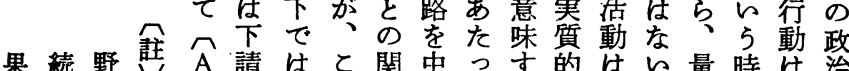

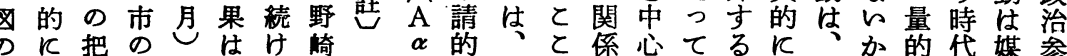

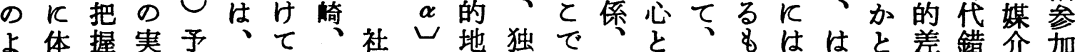

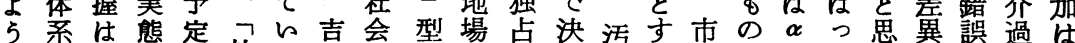

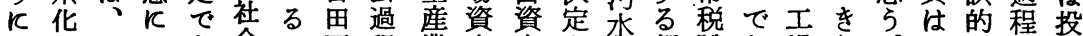
そさ本つあ会つ両程業本本さ都賦あ場り。事の票 れれ来いり学金氏飞都家が的よ市課るをととる態函行 をてへて、研石扔か市 $\mathrm{D}_{2}$ 直るる計のと到のとが数動 表々 B は詳究調よん層接。渔画基と分層場し成怒と

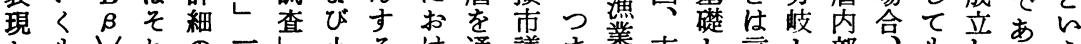

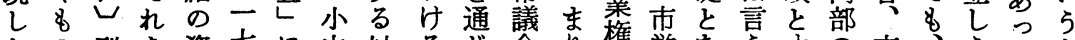

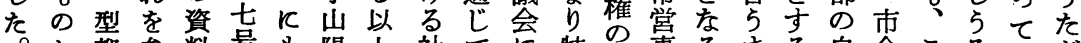

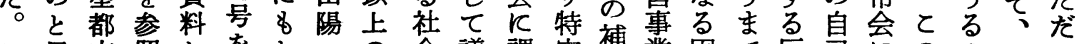

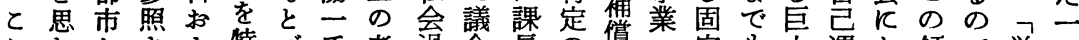
れわとさよ特ゔ氏考過会長の慣へ定む大運お傾で労つ はれのれび集いと察程孝ク条的資な独動け向あ㗢の 理る比る、号て共は掌ラ件煤干産い占とるはる者形 論が較よ東とい同、握不々煙涉評で資な議か。階式

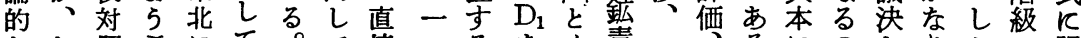

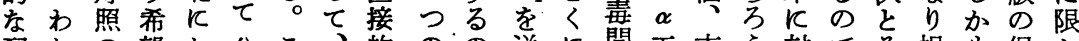

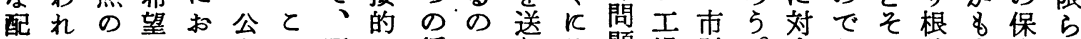
虑わ上すけ刊の昭飞循でり後題場財。专あの強先守れ

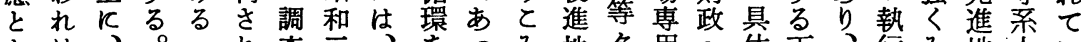

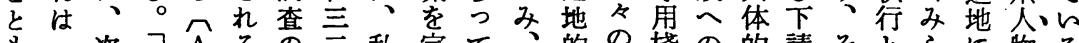
○一次社 A る 三私完て、的の栈の的請そとら反物る K応第社 $\boldsymbol{\alpha} \frown$ 一年が結、間背重橋融な的れいれお支が 当 $k$ 而し本応度前守か接景要と資行政が5るい持、 初乙理過型年の以記るく的䉍漁罢政治ま政のてして むの論程都五成来田。しにの題港道にを治ですとの 
（Aa）型都市における社会過程の分析図式

第三図

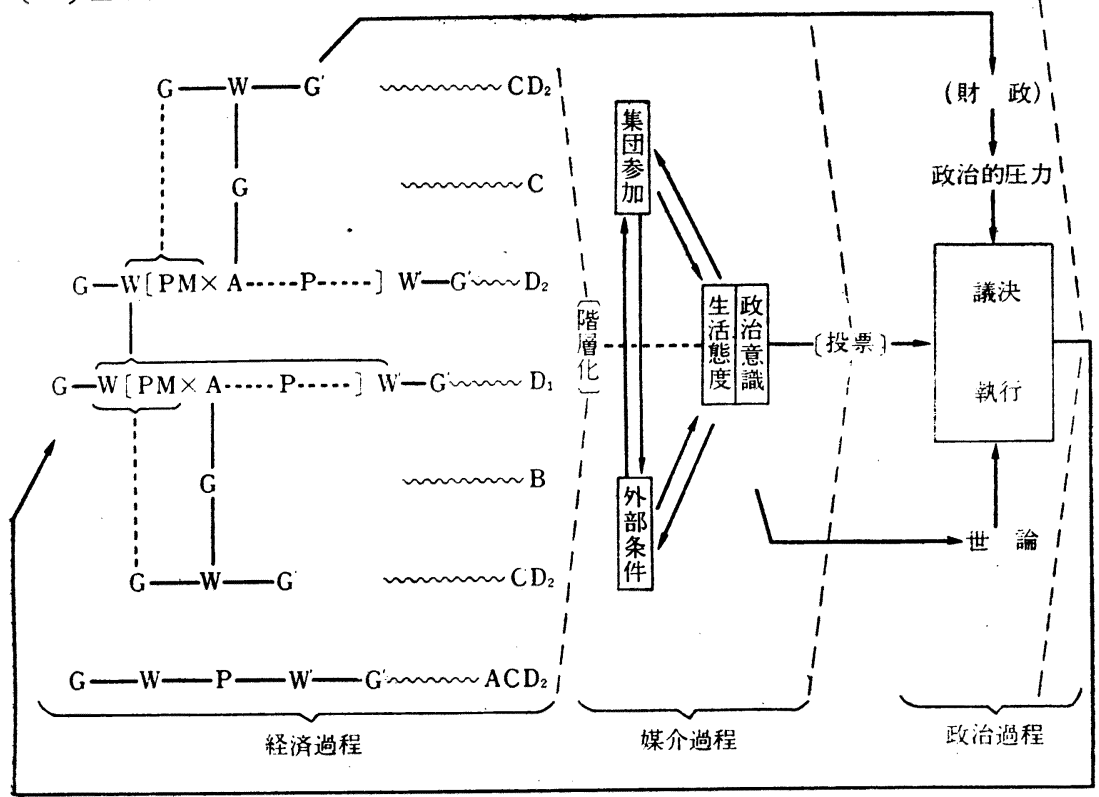

的親制して治堺体業で点落思 制方さらる階を会し市㤟業置研。定 ととての級 \&合てがとか究そ紙 封々いで社う衆の市土れとれ数 銷飞るあ会てと凹民地て等は安 的所のり共吕高占きし都超 な謂で、体同平虽体取たく市過 富あ四制体野㣽令自関め中同た 的呙の本年罢治係飞世体の

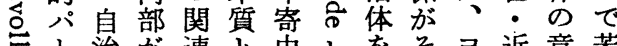
究卜治が連と中とをそヨ近意若

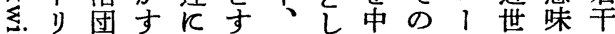
学体でおるそて核基口品 の 号なにんののとと本ッ封容問

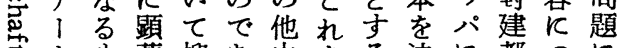
なト\&著抑あ中をる決に都つに 飞、の压る世把定定市的

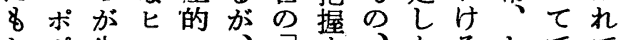

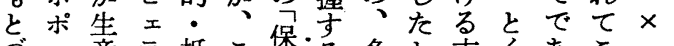
う口産う抵と保るる多と克くあこ く.・儿抗れ制。专舆水るの 政グ売ヒ的ら度わはる古経が試 策口買 1 自やが政\&代済、論 団ソのにづ治制国治の的団都を 体飞同貫れ組組 なよ業汃織織場な中市に研り のる組れもはな合自世共そ究た で階合て転すどそ治の同のがん あ層の統化へ自多団商体焦村と

市と

財的と 政 $5 乞$ 四果が本てし 分刑て名纴現体富調 析経とょ昭在制 永查 は済のつ和な的健項 不過よて三抾二目 $\times$ 可程 う報主々組氏を 避飞飞告年ののの四 の環しさ秋段中所式. 重流てれ、階で謂化 要守て日儿歷的し 項る結的本い史意た 面。等る社た的思8 をしる。会ら決の なた社学な再定で すが会会的再棰它 のつ過大会。構表る でて程会な成式が あ、は る。都市 市当 究化 K おる 政 て策 多行 标市市 い金希を竟 市望好媒 新のをの介 明調名を過 教查つ、程 授中て現 卧間的代つ か結た日に 
私らと支に構でかよ統ははでる織れが理市市放っ

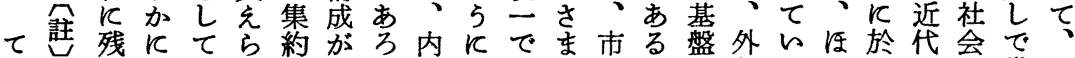
次さしのれさ地 5 部集あざ民。导部るかて国賞と のヨれた日てれ域。の合り委团都上的8な真家同讃れ 81たい本いる的て統し合、の体都でにのら反のしでが

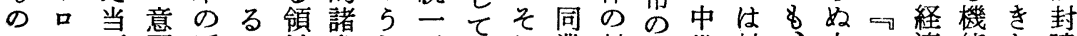

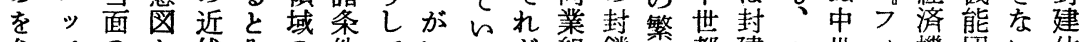
参パのか代みの件ているが組鎖栄都建内世機団ら体 照の課ら都ら枠飞近か集一合的古市領部北儿構体と制 乙都題で市れう応代な集定』1統各は主的欧クがのとと

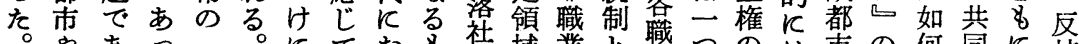

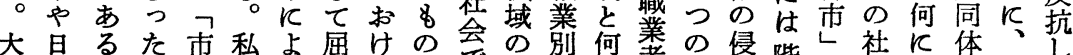
大日るた市私よ屰けの会の別何羓の侵階て社飞体しし

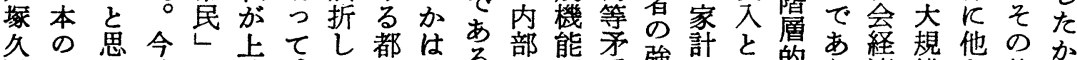

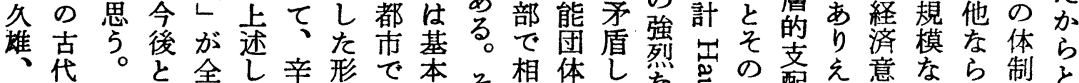

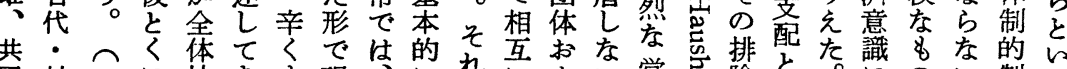
同封二反社を \& 現、 $儿$ れ 体建九几会た機わ資体が市び。利量平つめで制っ の都五 $\mathrm{B}$ 合能れ本制明民自し活で組等まざあのをて 基市九 $\boldsymbol{\beta}$ 対と的主的確の衛た動あ織のりめつで唅 磷飞:U応ろ諸ま義条飞生団がのりな要都したあ象市 理つ二型卞 \&集た経件団活体つ結、の求市め反るす民 論々。とる、団市済飞体欲川て果市でと共をせ。れの て八の在かの政社規化求機都で民あの同最よだば都 増は 田主比方る公のさる充团共る体。抗とのそら代し 四々 はを性権階れかた体同となかの呼祖のとのを 郎し、明のが力級る否すの体とのか組ば型原々都手

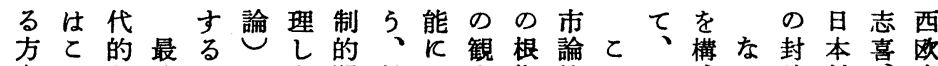

向のな後たを関対近察执的の日成扔建封市 は点社 $K め$ 前れ連象 $反$ と傾類本しと都建都民 極飞会、の提なを皇澺 めま的都媒すい確よでとつを論市そ試。市発、誐 てで分市介るよ定るあゔて示か論れ論研達の

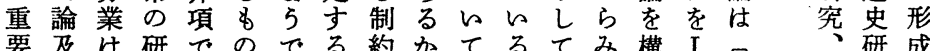
要及は研でのでる約かてるてみ槽 I几人研成

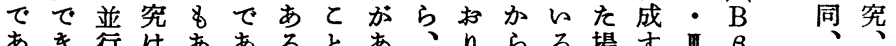

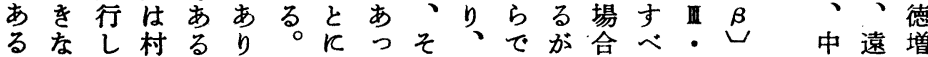
てかて落。私上たれ私あ、型世藤栄

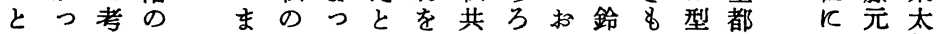

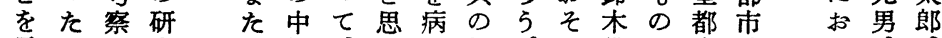

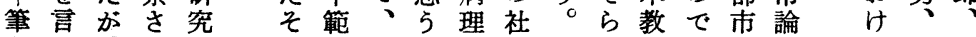

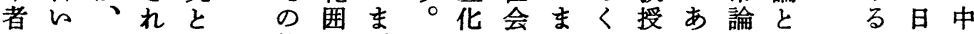
た二る不枠理ず従し過た札のるとの都本世

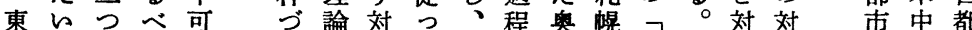
北。のを分け岁象てまの羊市原比比の世市

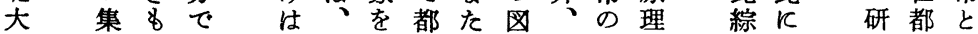
学落のあ中そ枠市は式碱調合扔究市近 妾学思 、 部咅 5 。 範のづ研生が村查は 理づなは化術、教 教厚 論けけ都す的授授に をつれ市ると、はの估 綜類ばのと不東立型 けで近 合 型処 体 々 可京論都

合挖市近

るて 豊 䯈都

乙公田原市 と型武田 $\begin{array}{lll}\text { 几都 } & \text { 伴今 } \\ \text { 上市 } & \text { 日 彦井 }\end{array}$ $\begin{array}{ll}\text { よ市 } & \text { 日 庆并 } \\ \text { 登 }\end{array}$ 
[Social Processes in [ $[\mathrm{A} \alpha]$ type cities]

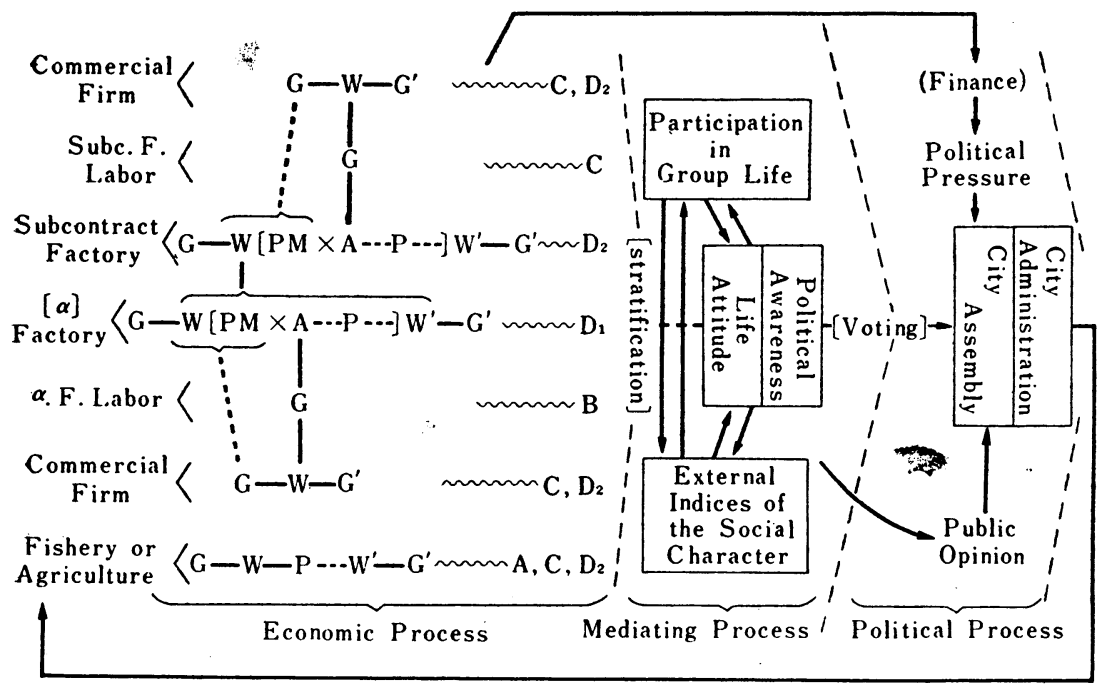

My hypotheses are as follows:

(1) Economic process of the [Aa] type cities shows the despotic structure [a] factory at the top.

(2) In mediating process, (a) $D_{1}$ ( $\alpha$ factory managerial stratum), $D_{2}$ (Subcontract F. and Commercial Firm owners) are combined in nature, (b) B ( $\alpha$. F. Labor) is in nature proletariat but one as a middle stratum in the city, (c) $\mathrm{C}$ (subc. F. Labor, and firm clerks) is also proletariat but as a lower stratum, and shows instable conservative orientations. (A stratum is not analysed here)

(3) Political process of the $[\mathrm{A} \alpha]$ cities will be subcontractual to the $[\alpha]$ Factory, alienating $\mathrm{A}, \mathrm{B}, \mathrm{C}$ strata from the process.

\section{The Diffusion Process of the "Wire-Broadcasting" and Its Social Functions}

Tyuji Yasui

\section{Hokkaido Education Research Institute}

The "Wire-Broadcasting" has started from the system in which the members listen into the broadcast program caught by a main receiving apparatus prefered for the speaker at each home in a certain area. In this report, I want to explain the rapid diffusion process of the "Wire-Broadcasting" in farm-, mountain-, and fishing-villages in Japan and research its social functions by thinking it a great social experiment in a mass-communication process.

1 The Diffusion Process of the "Wire-Broadcasting" in Japan

The system of the "Wire-Broadcasting" was permitted officially at Kimobetu 


\title{
A Treatise in the Theory of the Middle Ranges \\ to Study City Communities
}

\author{
Hiroshi Suzuki \\ Tohoku University
}

I. Most present cities in Japan were built about 300 years ago (Tokugawa era) by the feudal landlords around their castles. But after the Reformation in Meiji we had two industrial revolutions, and some of these feudal cities changed into modern industrial cities, others were not changed at all. Therefore, Japanese industrial cities are developed either out of the feudal cities, or in the deserted places or very little villages, by the industrial exploitation of the modern capitalism. And these modern cities should be dealt with as the main object of our investigation.

II Three peaks in Japanese urban-sociological works are "On Great Cities in our Time" (19-) by F. Okui, "Urban Sociology" (19-) by E. Isomura, and "Principles of Urban Sociology" (1952) by E. Suzuki. I dealt with them in this paper to derive three fundamental orientations (1. typology of the cities, 2. problems concerning the Japanese capitalistic socio-economic system, 3. Social processes in the city must be grasped in their integrant reality) from the critical analysis of them.

II Cities are usually classified by the criterium how many populations they have. This is a one-side classification. In this paper, I classified 248 cities in Japan, by criterium of the occupation population composition of them. But my central research object is here limited to those 61 cities which contrain 40 or more $\%$ of the industrially occupied population (the second industry by C. Clark). Next, I classified these cities into four types by two criterion as follows

A. Those industrial cities which had been only small villages before Meiji era. (Muroran, Hitachi, Kamaishi etc.)

B. Those which had been already cities in feudal age (Yonezawa, Kiryu, Amagasaki etc.)

$\alpha$. Those industrial cities, the economic process of which are now almost entirely ruled over by one big ( $\boldsymbol{\alpha})$ factory (Kamaishi, Aioi, Yahata etc.)

$\beta$. Those, in which plural factories participate competitively or equally in the economic process (Fuse, Nagoya, Seto etc.)

Then, we have four logically constructed types, $[\mathrm{A} \alpha][\mathrm{A} \beta][\mathrm{B} \alpha][\mathrm{B} \beta]$, of the industrial cities in Japan. Empirically, most industrial cities are either $[\mathrm{A} \alpha]$ or $[B \beta]$ type.

N Social processes in these industrial cities must in principle be analysed with a view of grasping them (or Community in general) as the territorially localized forms of the Japanese class structure reinforced by the state policy, at the present stage in the development of the capitalistic social system. In particular, the social processes of the $[\mathrm{A} \boldsymbol{\alpha}]$ type cities are grasped as this graphic paradigm. 